\title{
DESIGN INPUTS DOCUMENT: BOILING BEHAVIOR DURING FLOW INSTABILITY (U)
}

by

\author{
D. A. Coutts
}

Westinghouse Savannah River Company

Savannah River Site

Aiken, South Carolina 29808

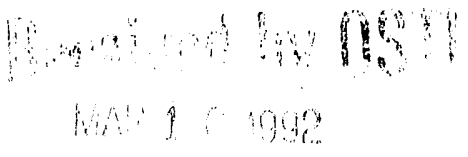

A paper proposed for presentation at the Review for Dissertation

Columbia, South Carolina December 1991

\section{DISCLAIMER}

\begin{abstract}
This report was prepared as an account of work sponsored by an agency of the United States Government. Neither the United States Government nor any agency thereof, nor any of their employees, makes any warranty, express or implied, or assumes any legal liability or responsibility for the accuracy, completeness, or usefulness of any information, apparatus, product, or process disclosed, or represents that its use would not infringe privately owned rights. Reference herein to any specific commercial product, process, or service by trade name, trademark, manufacturer, or otherwise does not necessarily constitute or imply its endorsement, recommanufacturer, or otherwise the United States Government or any agency thereof. The views and opinions of authors expressed herein do not necessarily state or reflect those of the United States Government or any agency thereof.
\end{abstract}

This paper was prepared in connection with work done under Contract No. DE-AC()9-89SR18035 with the U.S. Department of Energy. By acceptance of this report, the publisher and/or recipient acknowledges the U.S. Government's right to retain a nonexclusive, royalty-free license in and to any copyright covering this report, along with the right to reproduce and to authorize others to reproduce all or part of the copyrighted report. 


\section{Design Inputs Document Approval Page}

OSR 24-A271

Page 1 of 31

\section{Design Inputs Document Approval Page}

Task title Boiling Behavior During Flow Instability

DID revision number

Document no.

Task number, $91-063-1$

CustomerD. R. Muhlbaier Customer specification_NES-ETH-910252 Dated 4 /25/91 Name

Tilk/nodrev.

Preparer (Tack leader or designee).
D. A. Coutts
Prim name

\section{Approvals:}

Task leader (Customer's requirements argin the geaign specifications)

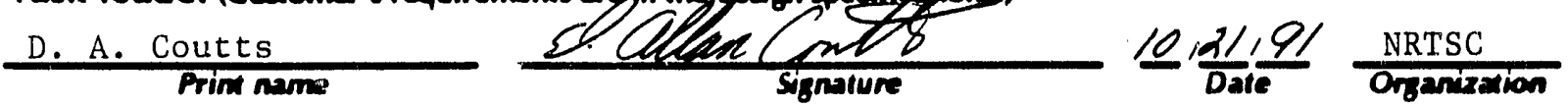

Facility Custodian (Concurrence with safiety requirements.)

R. Keklak Prinirame

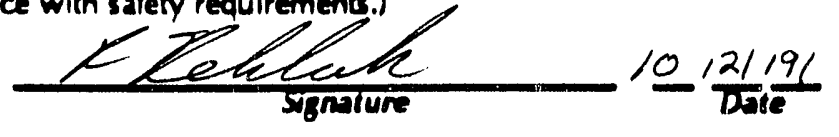

NRTSC

organzion

Technical reviewer (If required by responable manager; concurrence with technicd content.)

$$
\begin{aligned}
& \text { Priñ name } \\
& \text { जgnalure }
\end{aligned}
$$

Responsible manager (Level 4 or higher, concurnence yith dexign specification.)

D. R. Muhlbaier

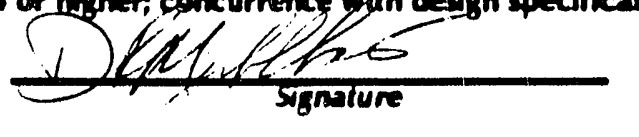

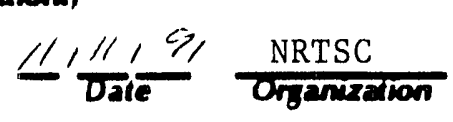

Lead designer (Acceptance of deaign requirementa.)

T. J. Steeper Printrom

$\frac{-1 / 1}{\text { Dagature }}$

Distribution (Controlled identification; inciude as a minimum designer(s) and customer.)

D. A. Coutts, 786-6A

R. Keklak, 786-A

D. R. Muhlbaier, $786-5 \mathrm{~A}$

T. J. Steeper, 786-5A

B. S. Johnston, 786-5A

Continued on atrachmemi $\mathrm{YeQ} \square \mathrm{Nd}$

Refer to NRTSC procedure QNP II-3, "Design Control," for acditional information. 


\section{Design Inputs Document Revisions Page}

OSR 24-Ki

DID revision number 0

Task number

$91-063-1$

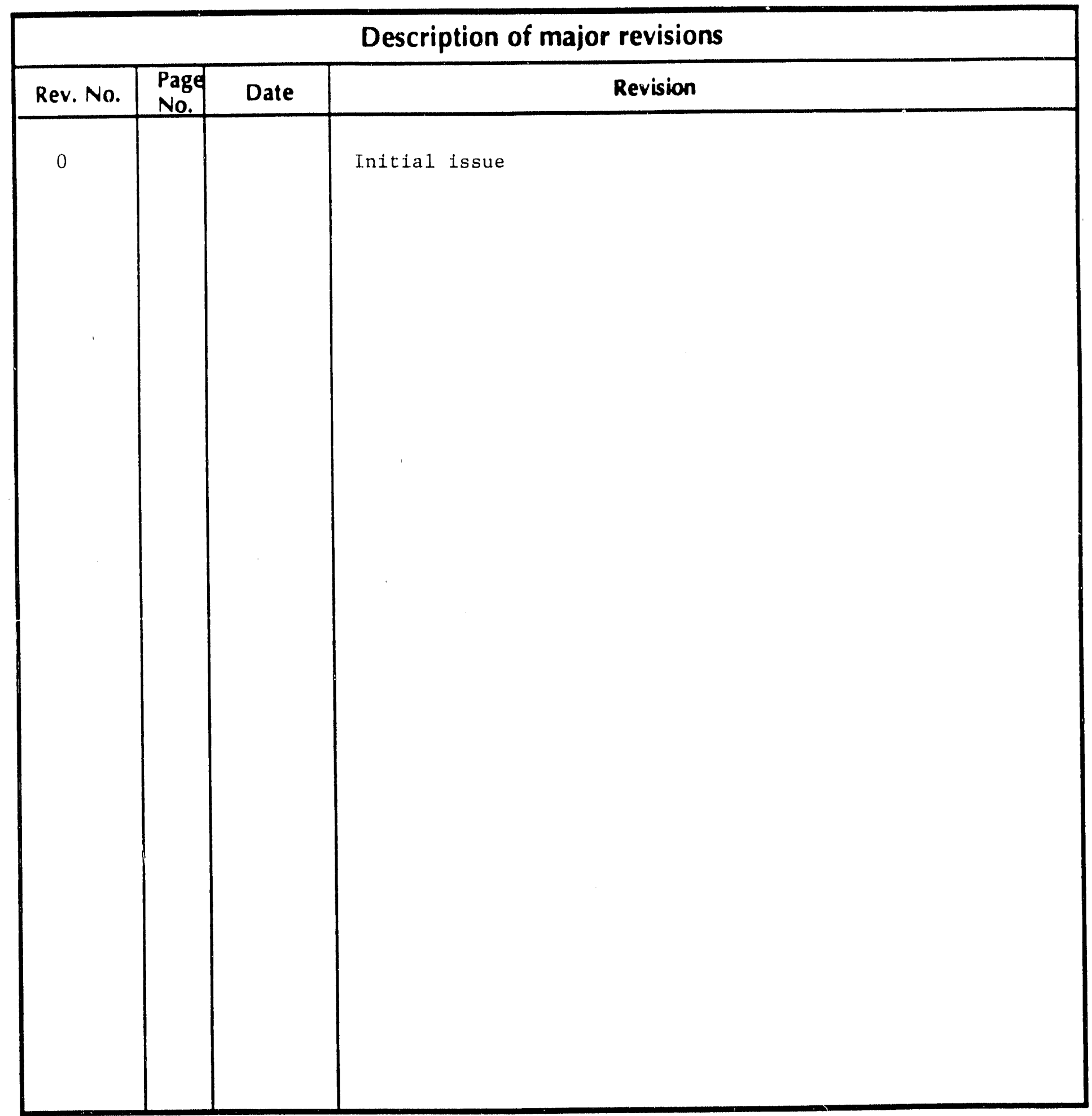

Refer to NRTSC procedure QAP III-3 "Design Control," for additional information. 
Table of Contents

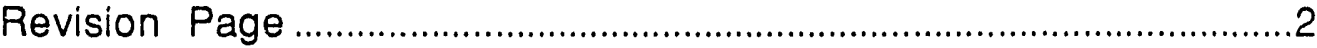

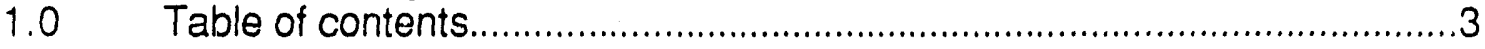

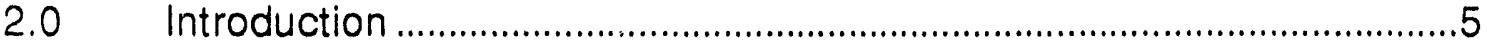

$2.1 \quad$ Background Information ...................................................................5

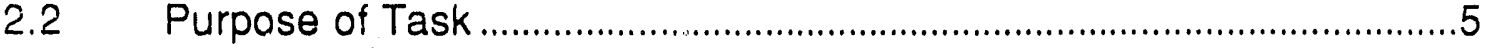

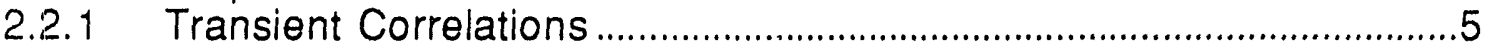

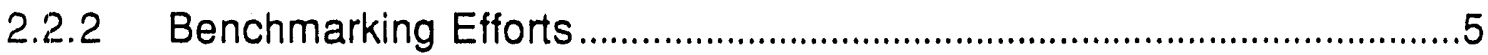

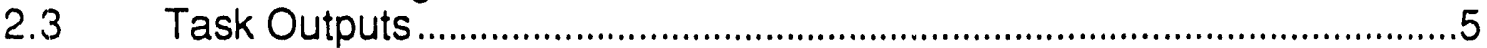

2.3.1 Rig Characterization..............................................................................6

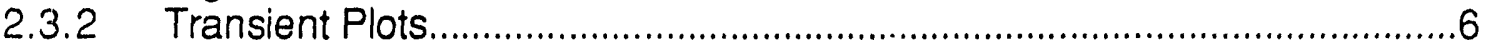

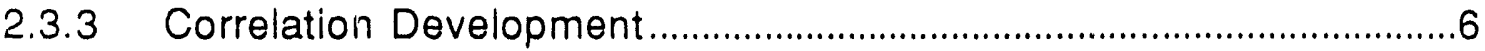

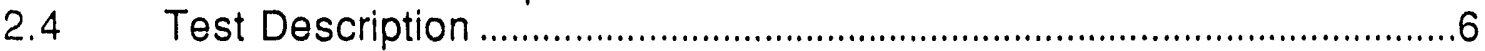

3.0 Design Classification ...........................................................................6

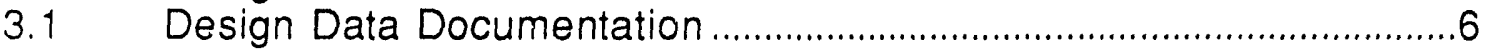

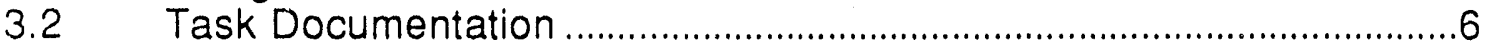

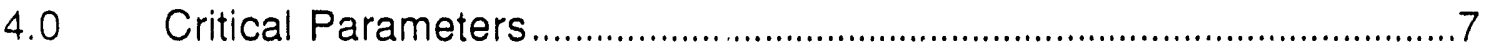

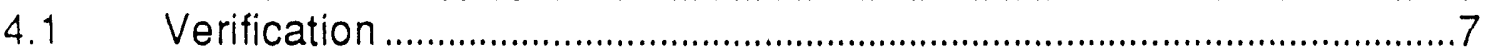

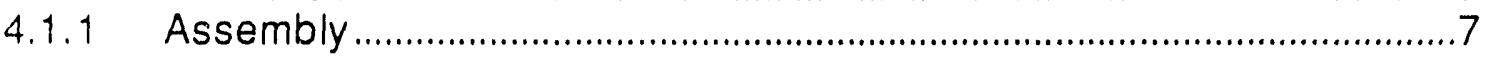

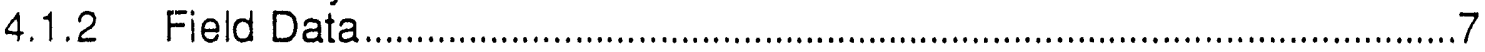

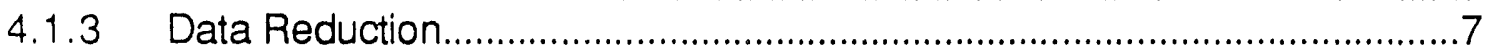

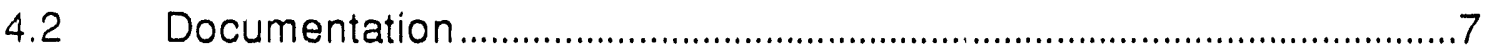

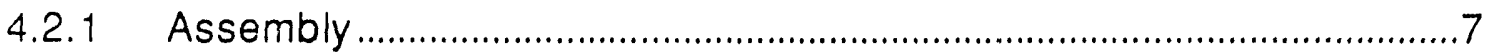

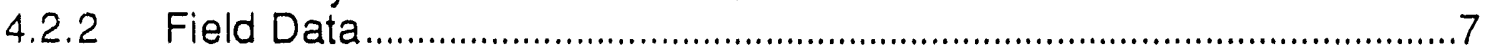

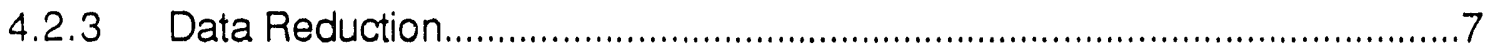

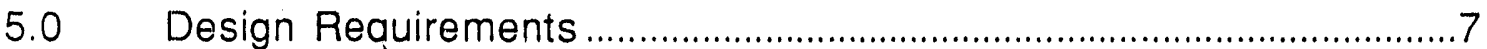

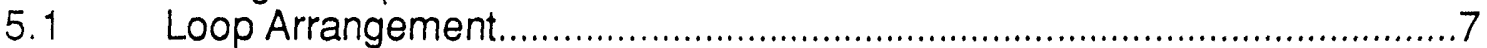

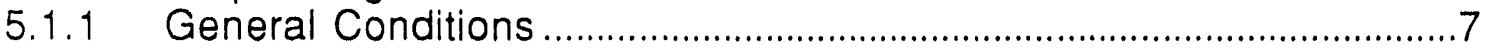

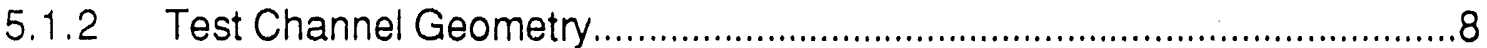

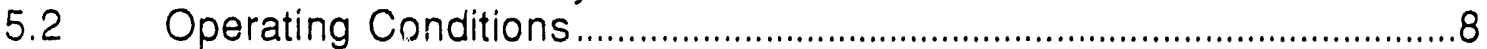

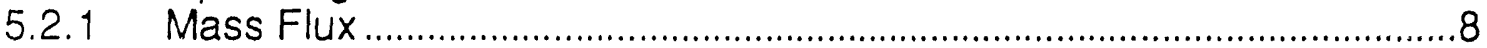

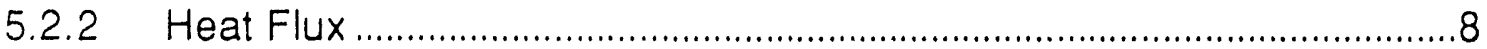

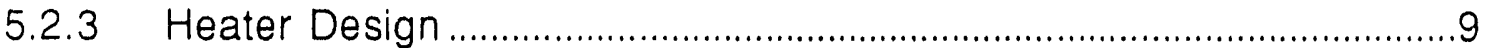

5.2.4 Transient Heat Flux ..........................................................................

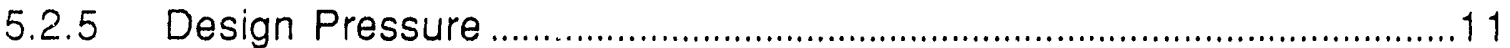

5.3 Technical Interfaces/Systems Interactions........................................13

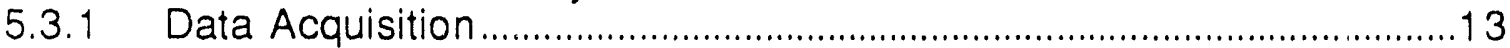

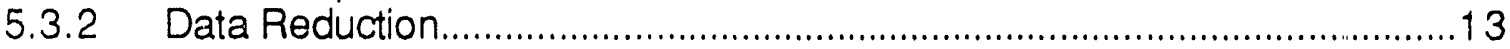

5.3.3 Data Evaluation...........................................................................

5.4 Safety/Process Hazard Reviews....................................................13

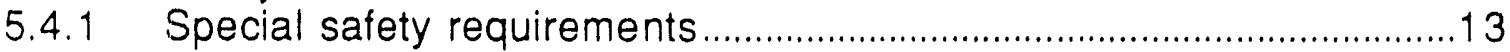

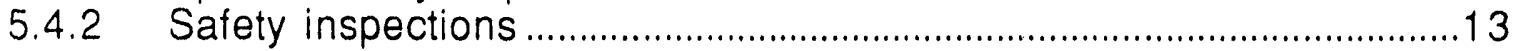

$5.5 \quad$ Applicable Codes and Standards ....................................................13

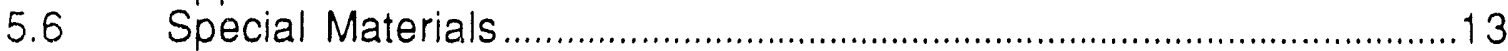

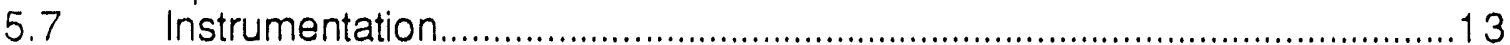

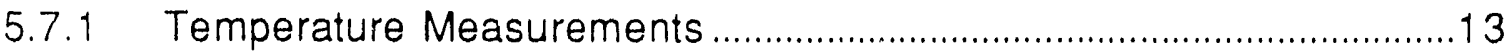

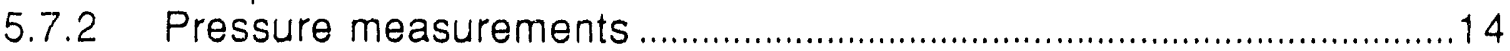

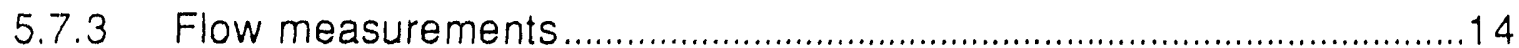


5.7.4 Electrical power measurements......................................................14

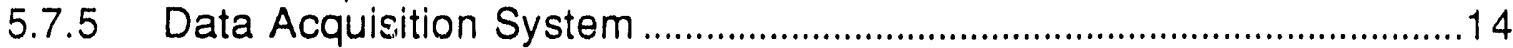

5.8 Anticipated Level 1 Procurements......................................................14

5.9 Anticipated Category 1 M\&TE Procurements ........................................14

5.10 Modeling and Scaling Requirements ................................................14

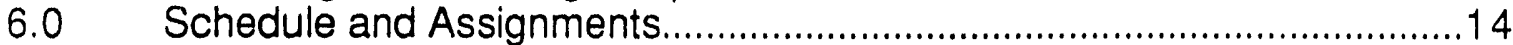

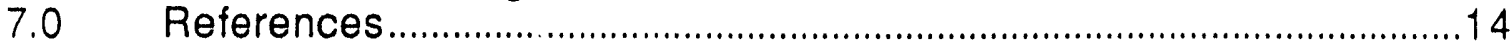

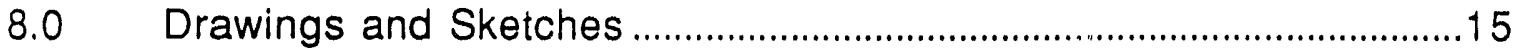

\section{List of Tables}

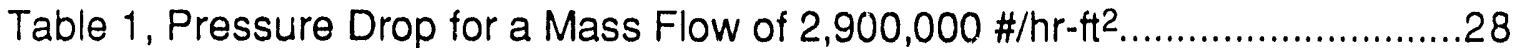

Table 2, Exit Calculation Data...........................................................................28

Table 3, Pressure Drop for a Heat Flux of 442,000 Btu/hr ...................................29

Table 4, Rupture Disk Design Information .............................................................29

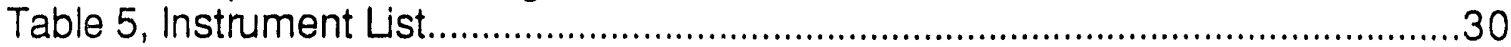

\section{List of Figures}

Figure 1, Flow Decay at End of Heated Section...................................................15

Figure 2, Quality at End of Heated Section........................................................16

Figure 3, Fluid Temperature at End of Heated Section .......................................16

Figure 4, Heated Section Channel Pressure Drop .............................................17

Figure 5, Time to Minimum Pressure Drop .........................................................17

Figure 6, Test Loop Arrangement.................................................................

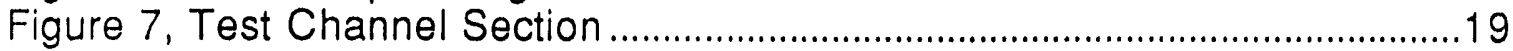

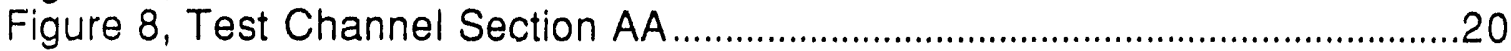

Figure 9, Test Channel Section BB ................................................................21

Figure 10, Fluid Property Instrument Locations ..................................................22

Figure 12, Pressure Transducer Locations........................................................23

Figure 13, Heated Plate Thermocouple Positions.................................................24

Figure 14, Heated Plate Thermocouple Installation Details................................25

Figure 15, Instrument Package Installation........................................................26

Figure 16, Instrument Package Details..............................................................27 


\subsection{INTRODUCTION}

\subsection{Background Information}

The coolant flow in a nuclear reactor core under normal operating conditions is kept as a subcooled liquid. This coolant is evenly distributed throughout the multiple flow channels with a uniform pressure profile across each coolant flow channel. If the coolant flow is reduced, the flow through individual channels will also decrease. A decrease in coolant flow will result in higher coolant temperatures if the heat flux is not reduced. When flow is significantly decreased, localized boiling may occur. This localized boiling can restrict coolant flow and the ability to transfer heat out of the reactor system. The maximum operating power for the reactor may be limited by how the coolant system reacts to a flow instability ${ }^{1}$. One of the methods to assure safe operation during a reducing flow instability, is to operate at a power level below that necessary to initiate a flow excursion. Several correlations have been used to predict the conditions which precede a flow excursion?2. These correlations rely on the steady state behavior of the coolant and are based on steady state testing.

\subsection{Purpose of Task}

2.2.1 Transient Correlations - This task will evaluate if there are any deviations between the actual transient flow excursion behavior and the flow excursion behavior based on steady state correlations (ONB, OSV, and CHF). Correlations will be developed which will allow a comparison between the time to excursive behavior predicted using steady state techniques and the actual time to excursive behavior.

2.2.2 Benchmarking Efíorts - Bankoff, Lee and Knaani have completed a literature review 3 on Forced-Convection Subcooled Nucleate Boiling. The review documented four ONB models, 11 OSV models, 3 bubble houndary layer modes and 8 void fraction models. All of the works are based on steadystate forced-convection, subcocled nucleate boiling. No experimental studies were identified which address transient forced-convection, subcooled nucleate boiling. The next step in their program will be to use the literature review us a basis to develop a theoretical model for transient downflow instability. This task will provide data to be used to benchmark and verify the theoretical model.

\subsection{Task Outputs}

2.3.1 Rig Characterization - Existing steady state correlations for the prediction of ONB, OSV and CHF will be evaluated as part of the rig characterization.

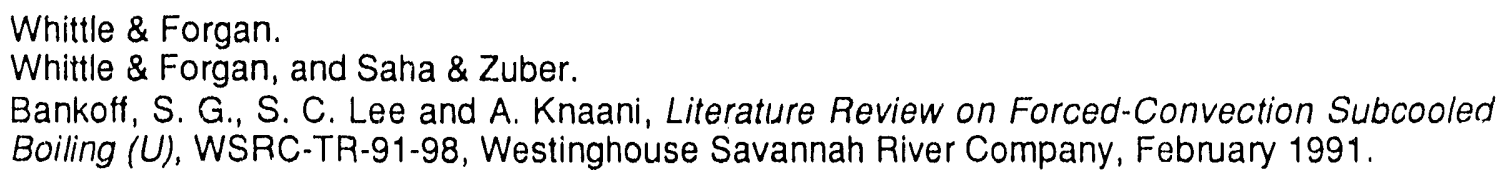


This characterization data will be used as the datum for discussion of transient boiling behavior. The characterization effort will include:

1. Characterize the test loop when flowing subcooled water under steadystate isothermal conditions.

2. Characterize the test channel when flowing saturated steam under steady-state isothermal conditions.

3. Characterize the test channel when flowing subcooled water under transient isothermal conditions.

4. Characterize the steady-state $S$ curves for the test channel at a limited number of power levels (2 or 3 ).

2.3.2 Transient Plots - Pressure and temperature transient plots (See Figures 1, 2,3 , and 4) will be prepared for a limited number of power levels.

2.3.3 Correlation Development - Correlations which compare the calculated time to ONB, OSV, minimum pressure drop, or CHF using existing steady state correlations (See Figure 5) with the actual measured time to the milestone event (ONB, OSV, etc) will be prepared.

2.4 Test Description - The test will be performed in the Heat Transfer Laboratory, Building 786-A. The test rig will consist of a vertical flat channel rig which has a heated section about 4 feet long and a nominal flow area of $0.125^{\prime \prime} \times 3 "$.

The transient flows will be produced using a positive displacement pump. The design shall allow in future installation of a small bypass around the heated channel. Because of the potential for density wave oscillations the installation of dead pockets of fluid in the test loop must be avoided. (This includes the installation of tees for future tie-ins.)

\subsection{DESIGN CLASSIFICATION}

3.1 Design Data Documentation - The design classification for this task is General Services since there are no special hazards, and no major loss criteria exceeded. (Note: This statement is directed towards the design of the equipment. The design classification is not a function of how data will be used.)

3.2 Task Documentation - The design information which impacts the critical parameters listed in this document shall be retained to allow inclusion in the task records. (This is directed at retaining as-built dimensions and clearances which will be used in test data reduction.) 


\subsection{CRITICAL PARAMETERS}

\subsection{Verification}

4.1.1 Assembly - Critical parameters which must be measured during system assembly may be verified using the self-checking process. Peer verification and Independent verification of critical assembly parameters is not required but may be implemented.

4.1.2 Field Data - Critical parameters measured during system operation (data collection) and run-in shall be verified using the self-checking process.

4.1.3 Data Reduction - Critical parameters calculated during data reduction shall be verified using the self-checking process.

\subsection{Documentation}

4.2.1 Assembly - The method used to document critical parameters which must be measured during system assembly shall be recorded in the task laboratory notebook by the test engineer or his designate. There is no preference on how assembly critical data is documented.

4.2.2 Field Data - Critical parameters measured during system operation (data collection) and run-in shall be documented in the task laboratory notebook, field data sheets or M\&TE history files. The documentation method shall be recorded in the task laboratory notebook.

4.2.3 Data Reduction - Calculation sheets which are held in the task records shall be used to document critical parameters calculated during data reduction.

\subsection{DESIGN REQUIREMENTS}

\subsection{Loop Arrangement}

5.1.1 General Conditions - The test apparatus will consist of a single rectangular heated channel in a downflow configuration as shown in Figure 6. Water will be circulated using a variable speed positive displacement pump. The capacity of system will be approximately $15 \mathrm{gpm}$. Flow discharge from the pump will be measured using a turbine meter. Heated water and steam discharged from the heated test section will be cooled with a heat exchanger. The distance between the test channel and this heat exchanger should be kept to a minimum to reduce pressure losses. Provisions shall be made to allow the injection of water for quenching. The temperature at the exit of the pump will be controlled by the heat exchanger secondary coolant flow. The pressure at the suction of the pump will be controlled by use of a standpipe.

Prior to a flow transient being initiated the apparatus will be run at steady state in a fully subcooled condition. The pump flow will be reduced to induce the 


\section{Design Input Document, Boiling Behavior During Flow Instability}

flow transient. As the flow through the channel decreases vapor is expected to form at the end of the heated section. As the transient proceeds the vapor nucleation sites will move further up the channel and some vapor will start to leave the heated wall and enter the core flow. During this transient the frictional pressure drop and fluid acceleration will increase. The maximum expected averaged operating pressure will be 30 psig. This maximum is not a phenomena property, it is an apparatus design limit. The 30 psig maximum condition should provide an adequate variety of operating conditions. A higher operating pressure is preferred. The objective should be to provide a maximum operating pressure of 100 psig.

5.1.2 Test Channel Geometry - One of the primary goals of this test program is to visually observe when the onset of vapor nucleation (equivalent to the steady state ONB) and onset of significant vapor generation (equivalent to the steady state OSV) first occur. To allow this observation the channel must be equipped with vision panels. Vision panels will be provided on three sides of the flow channel. The fourth side of the channel will be the heated surface.

The flow area of 0.125 inches by 3 inches is considered the minimum size which would allow adequate observation of the flow conditions after consideration of the pressure boundary requirements. (See Figures 7, 8, 9, and 10.)

The length of the heated section was selected to allow operation of the test rig at two different inlet subcoolings. The design is based on the Whittle and Forgan correlation and a $5^{\circ} \mathrm{C}$ difference between the applicable temperatures.

\begin{tabular}{|c|c|c|}
\hline $\begin{array}{c}\text { Inlet Temperature } \\
{ }^{\circ} \mathrm{C}\left({ }^{\circ} \mathrm{F}\right)\end{array}$ & $\begin{array}{c}\text { Saturated } \\
\text { Temperature } \\
{ }^{\circ} \mathrm{C}\left({ }^{\circ} \mathrm{F}\right)\end{array}$ & $\begin{array}{c}\text { Critical } \\
\text { Temperature } \\
{ }^{\circ} \mathrm{C}\left({ }^{\circ} \mathrm{F}\right)\end{array}$ \\
\hline $60(140)$ & $109(228)$ & $99(210)$ \\
\hline $85(185)$ & $109(228)$ & $104(219)$ \\
\hline
\end{tabular}

For these conditions the temperature ratio will be 0.80 so the required length to heated diameter ratio $\left(L_{H} / D_{H}\right)$ to achieve the minimum pressure drop would be 100 . The required heated length would then be 4 feet.

The unheated inlet will be two feet (100 hydraulic diameters, $\mathrm{De}_{e}$ ) and the exit will be one foot ( 50 hydraulic diameters, $D_{e}$ ). The exit will be kept shorter because of the two-phase pressure drop in this section. The overall length of the test section will be about nine feet.

\subsection{Operating Conditions}

5.2.1 Mass Flux - The mass flux will be selected based on the Reynolds number calculated based on the conditions prior to the transient. Three different flow conditions will be evaluated: $R e=1000,10,000$ and 60,000 . 
5.2.2 Heat Flux - The maximum required heat flux will be for the highest Reynolds number and an inlet temperature of $140^{\circ} \mathrm{F}$. (See Table 1 for fluid property data.)

$$
\begin{aligned}
& V_{0}=\frac{0.016 \frac{\mathrm{ft}^{2}}{\mathrm{hr}}}{0.02 \mathrm{ft}}(60,000)=48,000 \mathrm{ft} / \mathrm{hr} \\
& V_{\text {crlical }}=\frac{48,000 \mathrm{ft} / \mathrm{hr}}{1.2}=40,000 \mathrm{ft} / \mathrm{hr}
\end{aligned}
$$

Based on an energy balance the transient critical heat (minimum $\Delta p$ ) will be $442,000 \mathrm{Btu} / \mathrm{hr}$ for an initial Reynolds number of 60,000 . The steady state critical heat will be $530,000 \mathrm{Btu} / \mathrm{hr}(155 \mathrm{~kW})$ at Re equal to 60,000 .

5.2.3 Heater Design - The heater design must provide the maximum heat required. This maximum heat would occur during steady state rig characterization at a Reynolds number of 60,000 . The maximum heat will be $(155 \mathrm{~kW})$. To provide this power using a single rectifier system ( 30 volt, 60 volt, 120 volt, 5000 amp limits) in Building 786-A a very small cross section is required. If three stainless steel heaters in parallel behind an aluminum plate are used then an appropriate cross section will be: 0.75 " by 0.0625 ". The calculated resistance will be:

$$
\mathrm{R}_{\Omega}=\frac{\left(32.9 \times 10^{-6} \Omega-\text { in }\right)(48 \text { inches })}{3(0.75 \text { inches })(0.0625 \text { inches })}=0.0112 \Omega
$$

For the required power of $155 \mathrm{~kW}$ the voltage and current would be: 41.7 volts and 3720 amps.

The 3/16" aluminum plate would be machined to allow the heater strips to be inserted. (See Figure 7.) The effective heat transfer distance to the flow channel would then be: 0.125 inches. The maximum aluminum and heater temperatures may be estimated using Fourier's equation. The heat transfer coefficient for the aluminum surface just prior to boiling is estimated from ${ }^{4}$ :

$$
\begin{gathered}
\mathrm{Nu}=\frac{h L}{k}=0.037\left(\frac{V_{\infty} L}{v}\right)^{0.8} \operatorname{Pr}^{1 / 3} \\
N_{z}=\frac{h_{z} z}{k}=0.0296\left(\frac{V_{0 . z}}{v}\right)^{0.8} \operatorname{Pr}^{1 / 3}
\end{gathered}
$$

For an average fluid temperature of $175^{\circ} \mathrm{F}$ for the highest flow and power conditions the exterior wall conditions will be: 


\section{Design Input Document. Boilling Behavior During Flow Instability}

$$
\begin{aligned}
& h=2250 \frac{\mathrm{Btu}}{\mathrm{hr} \mathrm{ft}^{2} \mathrm{~F}} T_{\text {wall, ave }}=410 \mathrm{~F} \\
& h_{L}=1798 \frac{\mathrm{Btu}}{\mathrm{hr} \mathrm{ft}^{2} \mathrm{~F}} T_{\text {wall, } z=L H}=505 \mathrm{~F}
\end{aligned}
$$

The interior aluminum temperature at the exit will be:

$$
\begin{gathered}
\phi=\frac{530,000 \mathrm{Btu} / \mathrm{hr}}{\left(4^{\prime}\right)\left(3^{\prime \prime}\right)}=\frac{\left(119 \frac{\mathrm{Btu}}{\mathrm{hr} \mathrm{ft} F}\right) \Delta T}{0.125^{\prime \prime}} \\
T_{\text {in }}=T_{\text {out }}+\Delta \mathrm{T}=505 \mathrm{~F}+46 \mathrm{~F}=551 \mathrm{~F}
\end{gathered}
$$

For a flat plate with a uniform distributed heat $\operatorname{source}^{5}$ such as the heater:

$$
\begin{gathered}
T-T_{\text {wall }}=\frac{W_{1}}{2 k}\left(x_{0}^{2}-x^{2}\right) \quad W_{1}=\frac{\phi}{x_{0}} \\
T-T_{\text {wall }}=\frac{\frac{12 \mathrm{in} / \mathrm{tt}}{0.0625^{\prime \prime}} \frac{530,000 \mathrm{Btu} / \mathrm{hr}}{3\left(4^{\prime}\right)\left(\frac{0.75^{\prime \prime}}{12 \mathrm{in} / \mathrm{ft}}\right)}}{2\left(12 \frac{\mathrm{Btu}}{\mathrm{hr} \mathrm{ft} \mathrm{F}}\right)}\left(\frac{0.0625^{\prime \prime}}{12 \mathrm{in} / \mathrm{ft}}-0^{2}\right)=153 \mathrm{~F} \\
T_{\text {in }}=T_{\text {wall }}+\Delta T=551^{\circ} \mathrm{F}+153^{\circ} \mathrm{F}=704^{\circ} \mathrm{F}
\end{gathered}
$$

This temperature is well below the melting temperature of aluminum $\left(1220^{\circ} \mathrm{F}\right)$ so should not present a problem even if there is a significant thermal contact resistance between the aluminum and heater plate.

5.2.4 Transient Heat Flux - The aluminum heating surface must respond rapidly to heat flux variations to allow power transient experimentation. To evaluate the transient behavior of the plate assume that it is an infinite slab at a uniform temperature of $228^{\circ} \mathrm{F}$ and the fluid surface is adiabatic. At time equal zero the inner wall temperature is instantaneously increased to $728^{\circ} \mathrm{F}$. The surface temperature can then be estimated as a function of time ${ }^{6}$ :

$$
\begin{array}{cc}
\frac{k}{h x_{0}}=0.0 & X=2.0=\frac{\alpha t}{x_{0}{ }^{2}} \\
Y_{\text {wall }}=\frac{T_{\text {wall }}-704}{228-704}=0.01 & T_{\text {wall }}=699^{\circ} \mathrm{F}
\end{array}
$$

$5 \quad$ Rohsenow and Choi, page 105.

6 Rohsenow and Choi, page 114. 


$$
t=\frac{2.0\left(\frac{0.125 "}{12 \mathrm{in} / \mathrm{tt}}\right)^{2}}{3.665 \frac{\mathrm{t}^{2}}{\mathrm{hr}}}=0.21 \text { seconds }
$$

The time required to achieve this transient is not thought to be significant since the flow transients are expected to be about five times slower. It is important to note that that the temperature will achieve $63.2 \%$ of the step change $\left(529^{\circ} \mathrm{F}\right)$ in 'J.05 seconds.

5.2.5 Disign Pressure - The test rig design pressure must be adequate to actileve OSV conditions for a Reynolds number of 60,000 and also allow the development of two-phase pressure drop as a function of flow characterizations. The pressure at the channel exit is assumed to be $5 \mathrm{psig}$. This will allow some pressure loss through the heat exchanger prior to the standpipe.

OSV Criteria - The pressure drop during heated subcooled flow is assumed equal to the pressure drop in adiabatic flow. For the conditions listed in Table 3 the maximum channel pressure drop across the 9 foot long channel will be 12 psi. (Elevation effects have been included in this calculation.) The inlet pressure for the flow channel will be 17 psig.

Two-Phase Flow Criteria - The pressure drop during two-phase operation will be a result of frictional pressure loss and velocity effects. The maximum total pressure drop through the test channel will be for the conditions listed in Table 1. This selection is based on the data presented in Table 3. (See Table 2 for fluid property data.)

The pressure drop across the channel exit transition from the rectangular test channel to a 2 " pipe will be 7 :

$$
\begin{gathered}
\frac{p_{\text {in }}-p_{\text {out }}}{\rho}+\frac{V_{\text {in }}^{2}-V_{\text {out }}^{2}}{2}=K_{\theta} \frac{V_{\text {in }}^{2}}{2} \\
K_{\theta}=1-2 \frac{A_{\text {ln }}}{A_{\text {out }}}+\left(\frac{A_{\text {ln }}}{A_{\text {out }}}\right)^{2} \\
K_{\theta}=1-2\left(\frac{0.0026}{0.0233}\right)+\left(\frac{0.0026}{0.0233}\right)^{2}=0.789 \\
\frac{p_{\text {in }}-p_{\text {out }}}{0.364 \# / \mathrm{ft}^{3}}=\frac{0.789 \frac{(697 \mathrm{fps})^{2}}{2}-\frac{697 \mathrm{fps}^{2}-77.8 \mathrm{fps}^{2}}{2}}{32.2 \frac{\# \mathrm{mt}}{\#_{f} \mathrm{~s}^{2}}}
\end{gathered}
$$




$$
p_{\text {in }}-p_{\text {out }}=-545 p s f=-3.8 p s i
$$

The pressure gradient across the test channel is provided in Table 3 for the same conditions as above. The total pressure drop is not the rig design pressure because of acceleration effects. (The highest absolute pressure occurs in the heated section of the channel.) The design pressure necessary to operate at this pressure drop will increase the rig design cost significantly. The pressure drop in the proposed rig will be less for lower flows. For a Reynolds number of 40,000 the estimated pressure drop is:

$$
\begin{gathered}
\frac{\Delta P_{40,000}}{66.3-5.0 p s i}=\left(\frac{40,000}{60,000}\right)^{2} \\
\Delta P_{40,000}=27.2 \text { psi }
\end{gathered}
$$

It is anticipated that a channel working pressure of 30 psig will provide an adequate range of test conditions. This should allow full rig operation at a Fieynolds number which approaches 40,000 .

Relief Protection Considerations - Because of the use of a positive displacement pump, high fluid velocities, and the potential for flashing vapor in the test section, relief protection for the flow channel is warranted. The rapid transients necessitate the use of rupture disks rather than relief valves. A rupture disk on both ends of the test channel may be warranted. Further evaluation is riecessary.

A potential disk which should be satisfactory would be a Fike HOV Series SST rupture disk. This disk is considered acceptable for cyclic duty (positive to negative), light pulsating duty and full vacuum. The rupture disk capacity can be estimated conservatively based on converting all water to steam at 45 psig.

$$
\dot{m}=\frac{530,000 \mathrm{Btu} / \mathrm{hr}}{915.4 \mathrm{Btu} / \mathrm{H}}=580 \# / \mathrm{hr}
$$

A 3/4" rupture disk would be required. The smallest disk available within the 55 psig rig design range would be a 1.5". (See Table 4 for rupture disk data.) The tolerances on this range would be:

Specified burst pressure

Standard manufacture's range

Normal rupture disk tolerance

$$
\begin{array}{cc}
21-45 \mathrm{psi} & 46 \text { to } 90 \mathrm{psi} \\
+16 \text { to }-8 \mathrm{psi} & +12 \text { to }-6 \mathrm{psi} \\
\pm 5 \mathrm{psi} & \pm 5 \mathrm{psi}
\end{array}
$$

For the specified disk the recommended operating margin is $70 \%$ :

$$
\mathrm{P}_{\text {rated }}=\frac{30 \mathrm{psi}}{0.7}=42.8 \mathrm{psi}
$$


Based on the information in Table 4, the design pressure for the channel will need to be at least 55 psi if standard manufacture's tolerances for rupture disks are to be specified for the relief protection. The design objective should be to allow operation at the highest possible operating pressures which would not result in a significant cost or schedule impact.

\subsection{Technical interfaces/Systems Interactions -}

5.3.1 Data Acquisition - Data will be recorded using Workbench software on Miacintosh computers.

5.3.2 Data Reduction - Operating conditions (pressure, temperature, and flowrate) will be time-averaged at each power level for steady state work. Tabular and graphical data will be reported for both steady state and transient tests.

5.3.3 Data Evaluation - Data will be evaluated as described in Section 2.3.

\subsection{Safety/Process Hazard Reviews}

5.4.1 Special safety requirements - There are several safety hazards that are inherent in this task. These include electrical hazards, hot pressurized equipment, boiling water and steam. The present operating procedures in the Heat Transfer Laboratory adequately address these hazards.

\subsubsection{Safety inspections}

Item 51 Inspection - After assembly of the test apparatus the test engineer is responsible to ensure that a safety inspection is completed as outlined by Item 51 of the Safety Manual.

Task Inspection - Prior to the operation of the heaters a task operational review shall be conducted by the test engineer and a minimum of two additional HTI/ETH engineers. The purpose of this inspection is to ensure that the equipment can be safety operated, critical data will be correctly handled, and the tests will be reproducible.

5.5 Applicable Codes and Standards - The pressure boundary systems shall comply with the structural and operational requirements of ANSI/ASME B31.3 or ASME B\&PVC Section VII. (It is recommended that the code of choice be B31.3 where a choice is acceptable.)

5.6 Special Materials - There are no special materials required for this task.

5.7 Instrumentation- The instrumentation necessary to conduct this task will be made available from the HTL instrument inventory except as noted in Table 5. 
5.7.1 Temperature Measurements - Except as noted all temperature measurements will be made with thermocouples. (See Figures 10, 13, 14, 15 and 16 for locations.) The mounting arrangement shown in Figure 14 will require some design development. The preferred arrangement is to fuse (braze) the thermocouple from the wetted side of plate to reduce the response time.

All thermocouples must be evaluated to establish their time constant. Provisions should be made to allow this evaluation after installation on the test loop.

5.7.2 Pressure measurements - All pressure transducers must be evaluated to establish their time constant. Provisions should be made to allow this evaluation after installation on the test loop. The locations of pressure transducers are provided in Figures 11 and 12.

5.7.3 Flow measurements - It is anticipated that the turbine meters in use presently in the HTL will provide responsive flow measurements for transients. This will need to be evaluated. All flow measurement devices must be evaluated to establish their time constant.

5.7.4 Electrical power measurements - A voltmeter and shunt system similar to those normally used in rectifier operation shall be used for the operation of this rig.

Provisions should be made to allow step increase in the applied power.

5.7.5 Data Acquisition System (DAS) - Data for this task shall be collected using a DAS as desuibed in Section 5.3.1.

5.8 Anticipated Level 1 Procurements - There are no anticipated level 1 procurements in support of this task.

5.9 Anticipated Category 1 M\&TE Procurements - Category 1 M\&TE procurements in support of this task will be limited to thermocouples and nonreversible temperature menitors. Some thermocouples will be installed in the heat rods during their manufacture. Thase thermocouples ma:" be purchased by the rod manufacturer or supplied by SRS. The temperature monitors are one-time-use devices which will be installed on selected rig locations to reduce the overall task uncertainty.

5.10 Modeling and Scaling Requirements - No special modeling and scaling requirements are anticipated.

\subsection{SCHEDULE AND ASSIGNMENTS}

The task schedule and assignments are listed in the Task Plan.

7.0 REFERENCES 
Bankoff, S. G., S. C. Lee and A. Knaani, Literature Review on ForcedConvection Subcooled Boiling (U), WSRC-TR-91-98, Westinghouse Savannah River Company, February 1991.

Rohsenow, Warren M., and Harry Choi, Heat, Mass and Momentum Transfer, Prentice-Hall inc., Englewood Cliffs, NJ, 1961.

Saha, P. and N. Zuber, "Point of Net Vapor Generation and Vapor Void Fraction in Subcooled Boiling", Proceedings of the 5th International Heat Transfer Conference,. Tokyo, Japan, September 3-7, 1974, pages 175-179.

Whittle, R. H. and R. Forgan, "A Correlation for the Minima in the Pressure Drop Versus Flow-Rate Curves for Sub-Cooled Water Flowing in Narrow Channels", Nuclear Engineering and Design 6, North-holland Publishing Company, Amsterdam, 1967, pg 89-99.

\subsection{DRAWINGS AND SKETCHES}

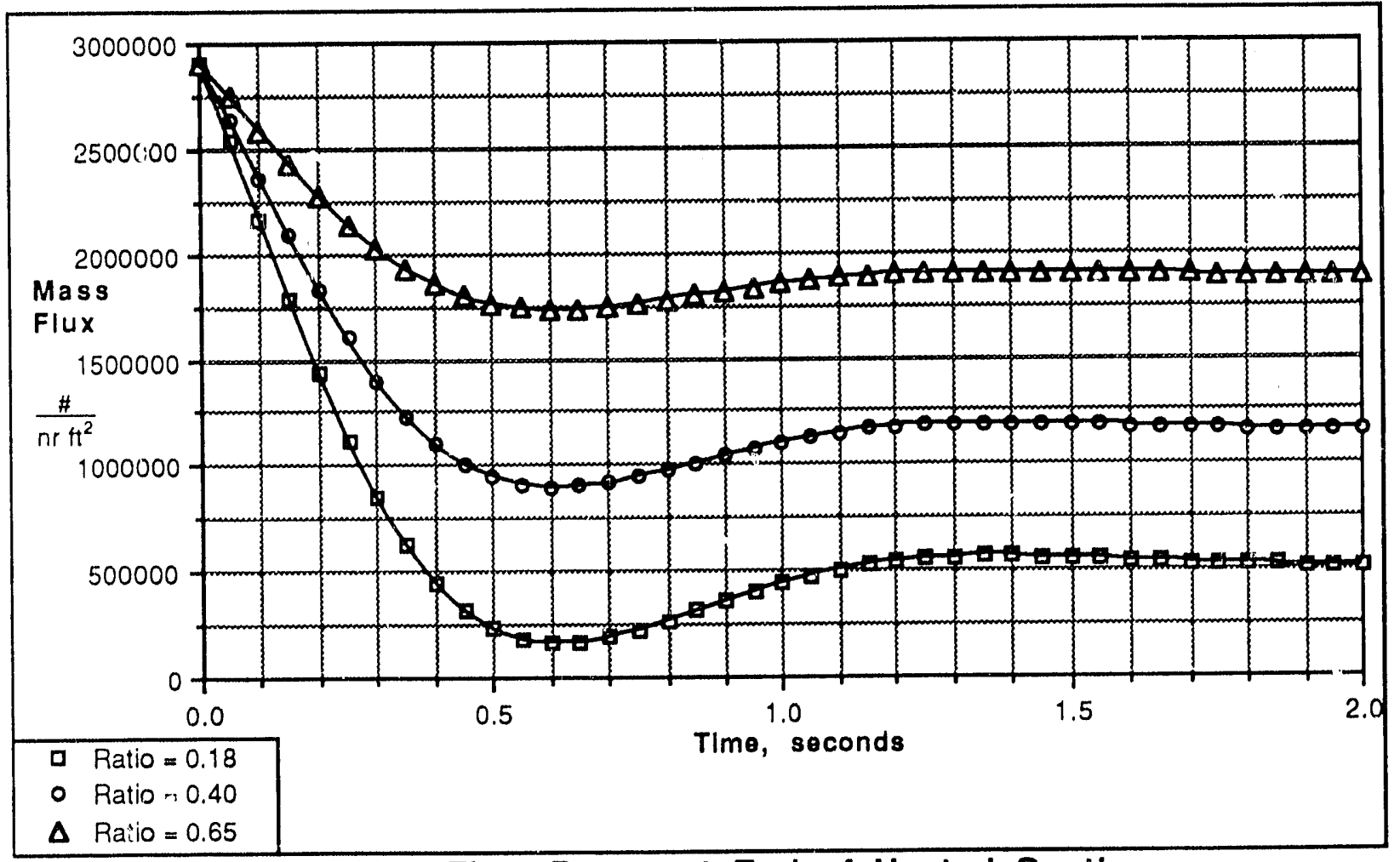

Figure 1, Flow Decay at End of Heated Section 


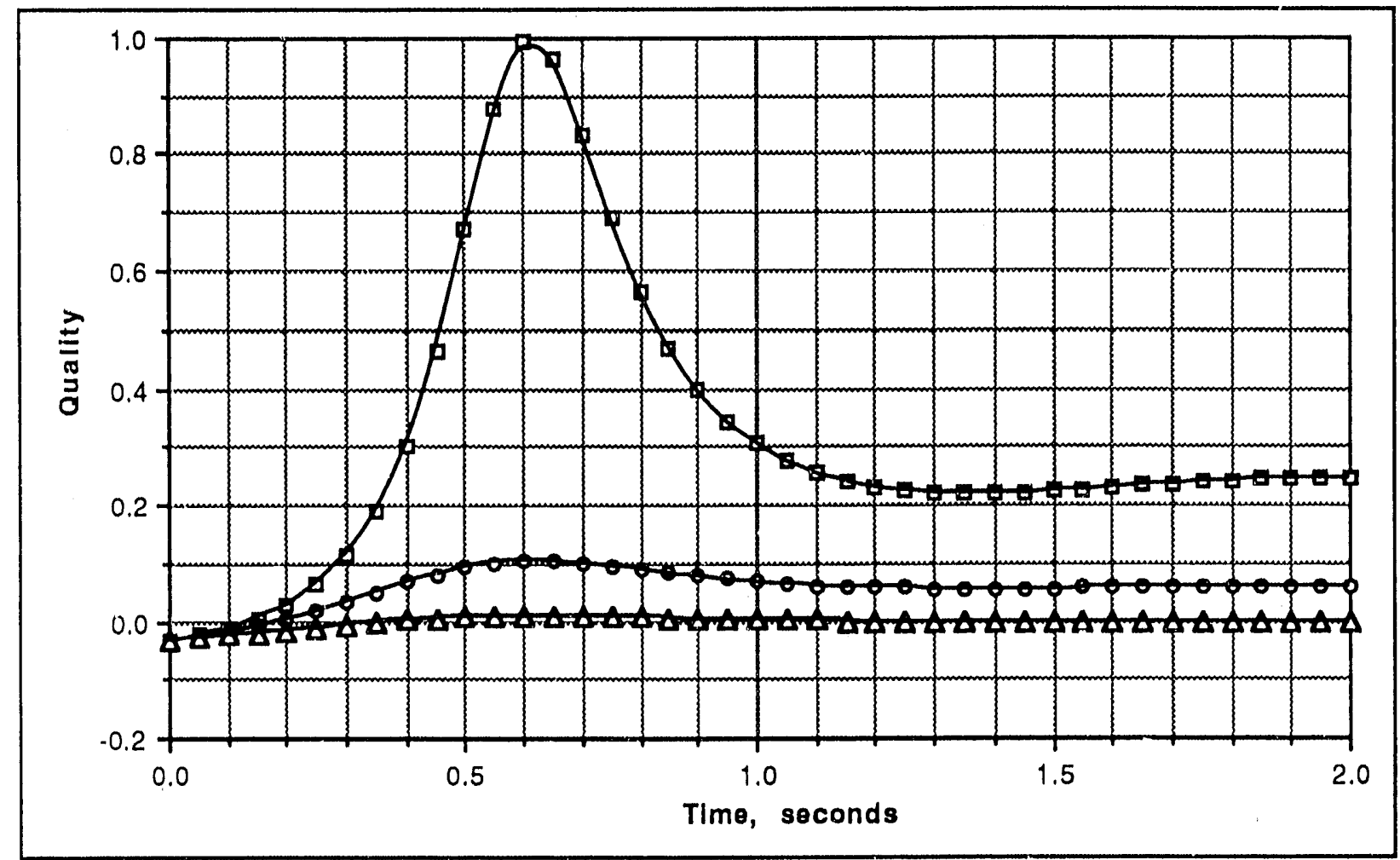

Figure 2, Quality at End of Heated Section

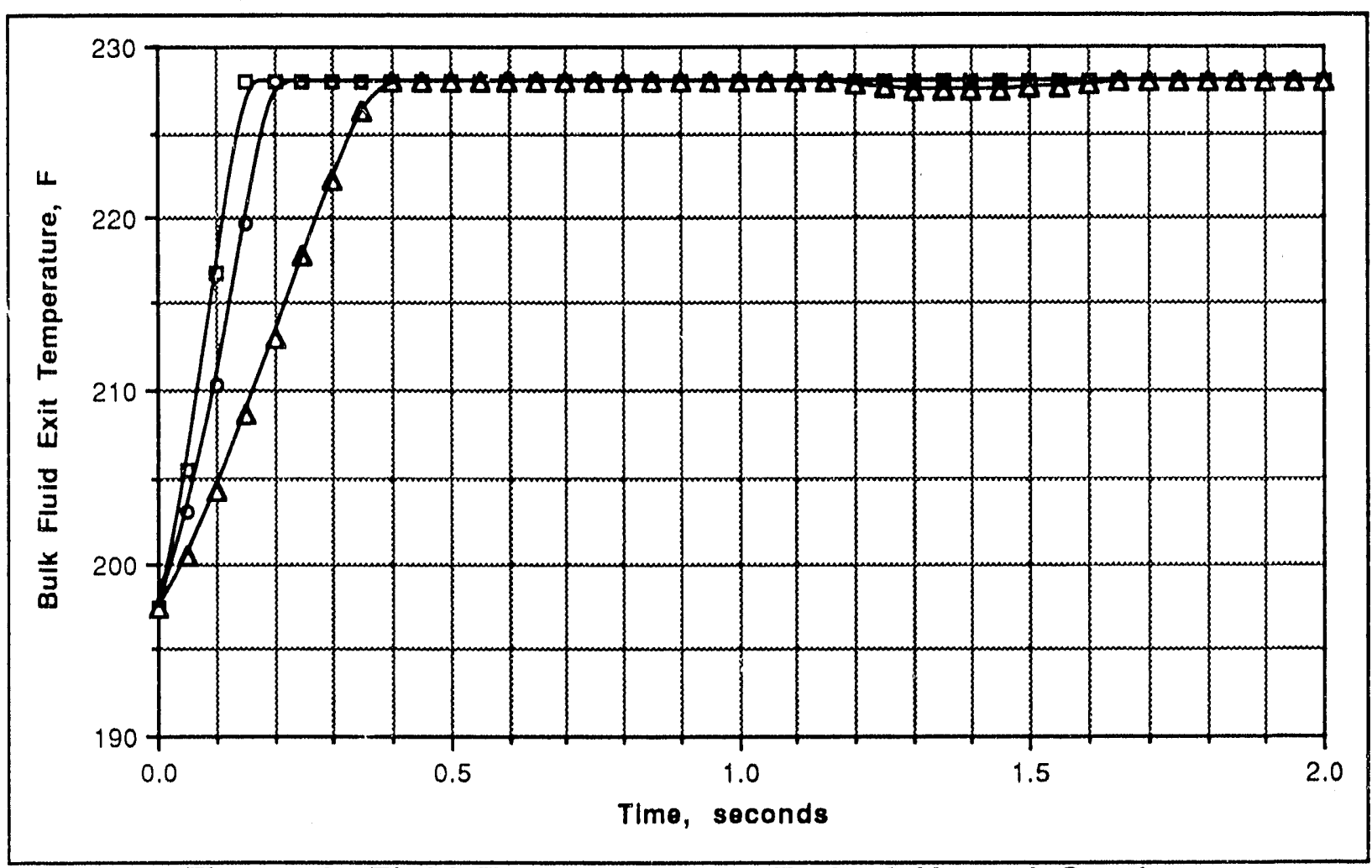

Figure 3, Fluid Temperature at End of Heated Section 


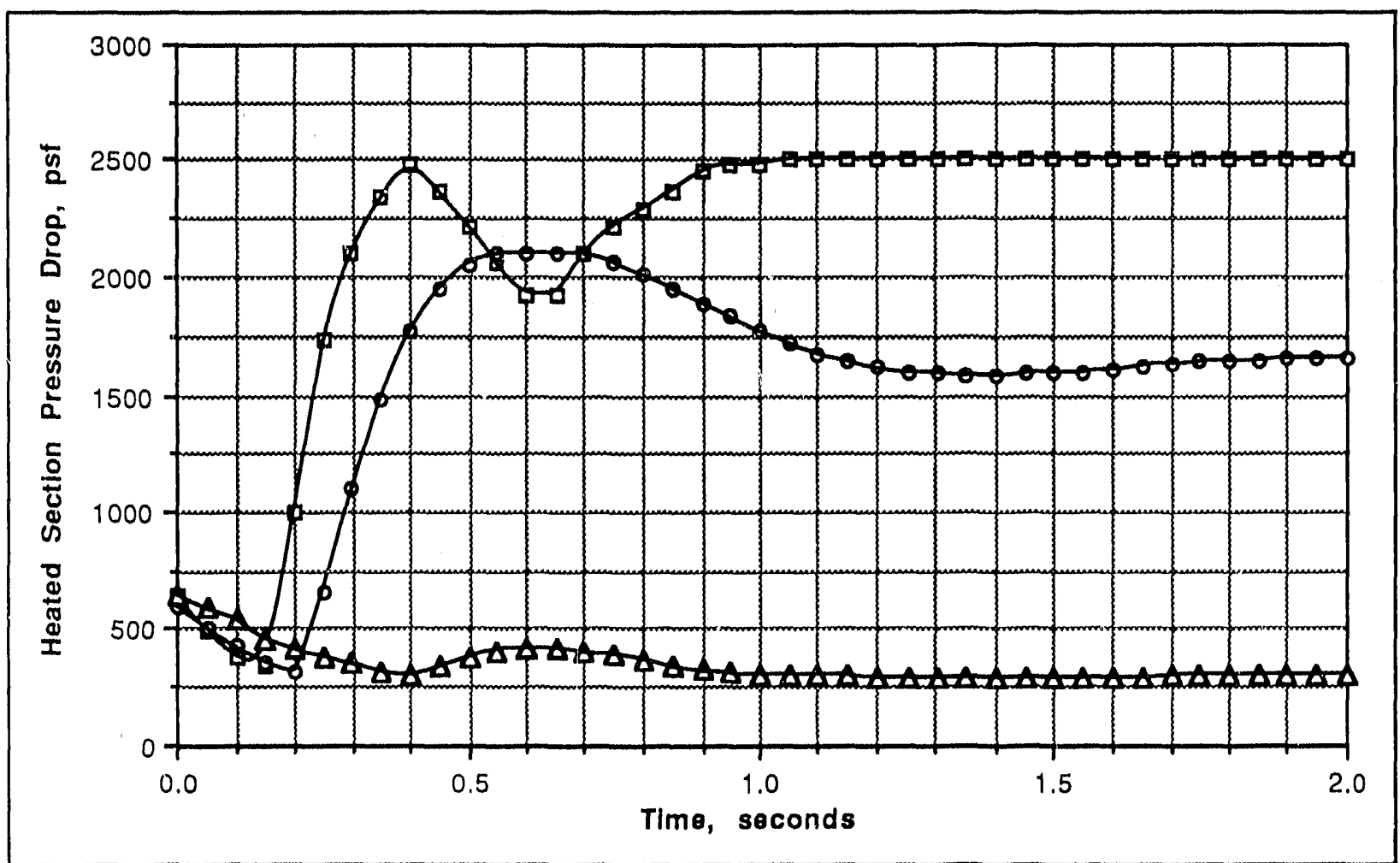

Figure 4, Heated Section Channel Pressure Drop

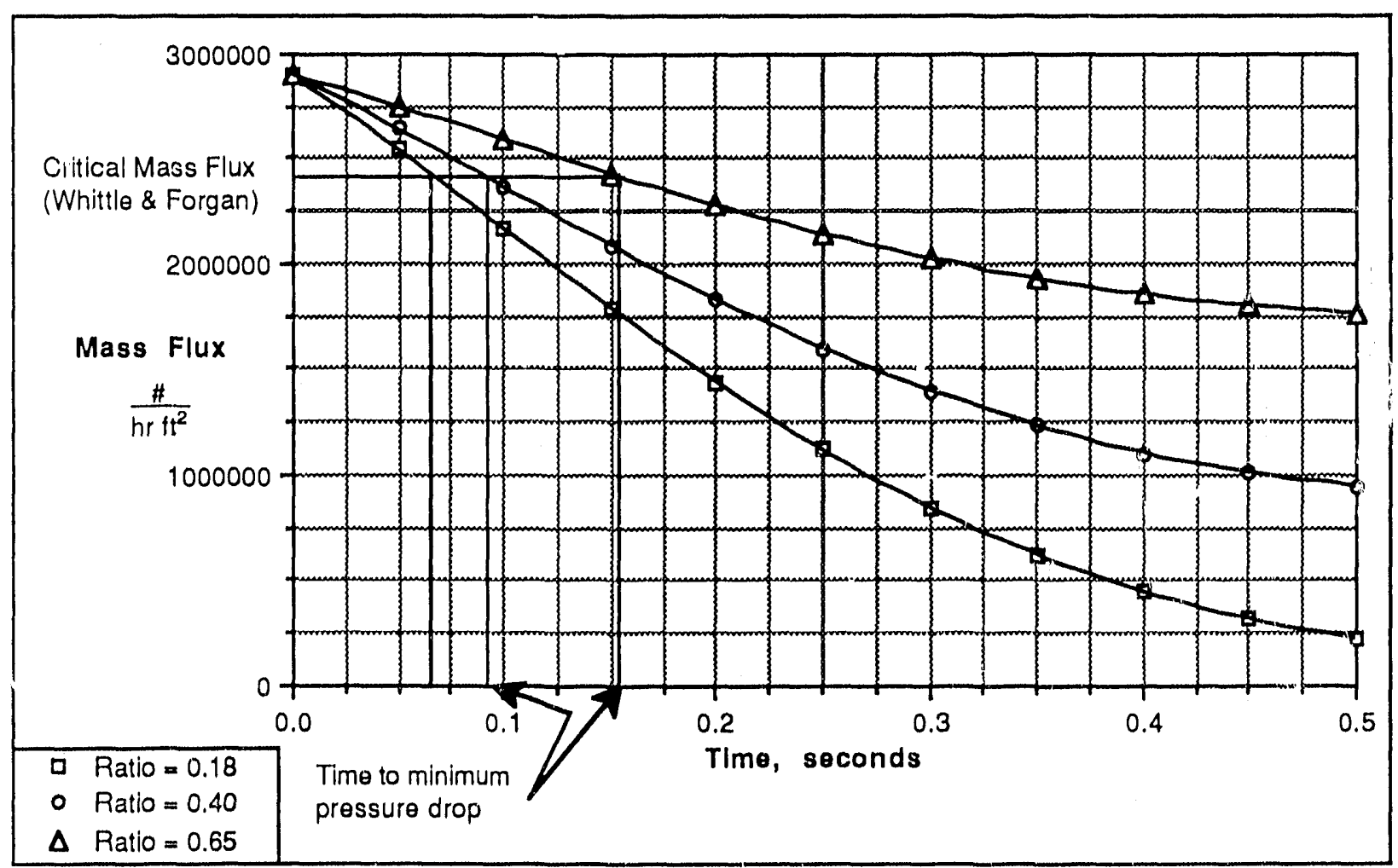

Figure 5, Time to Minimum Pressure Drop 


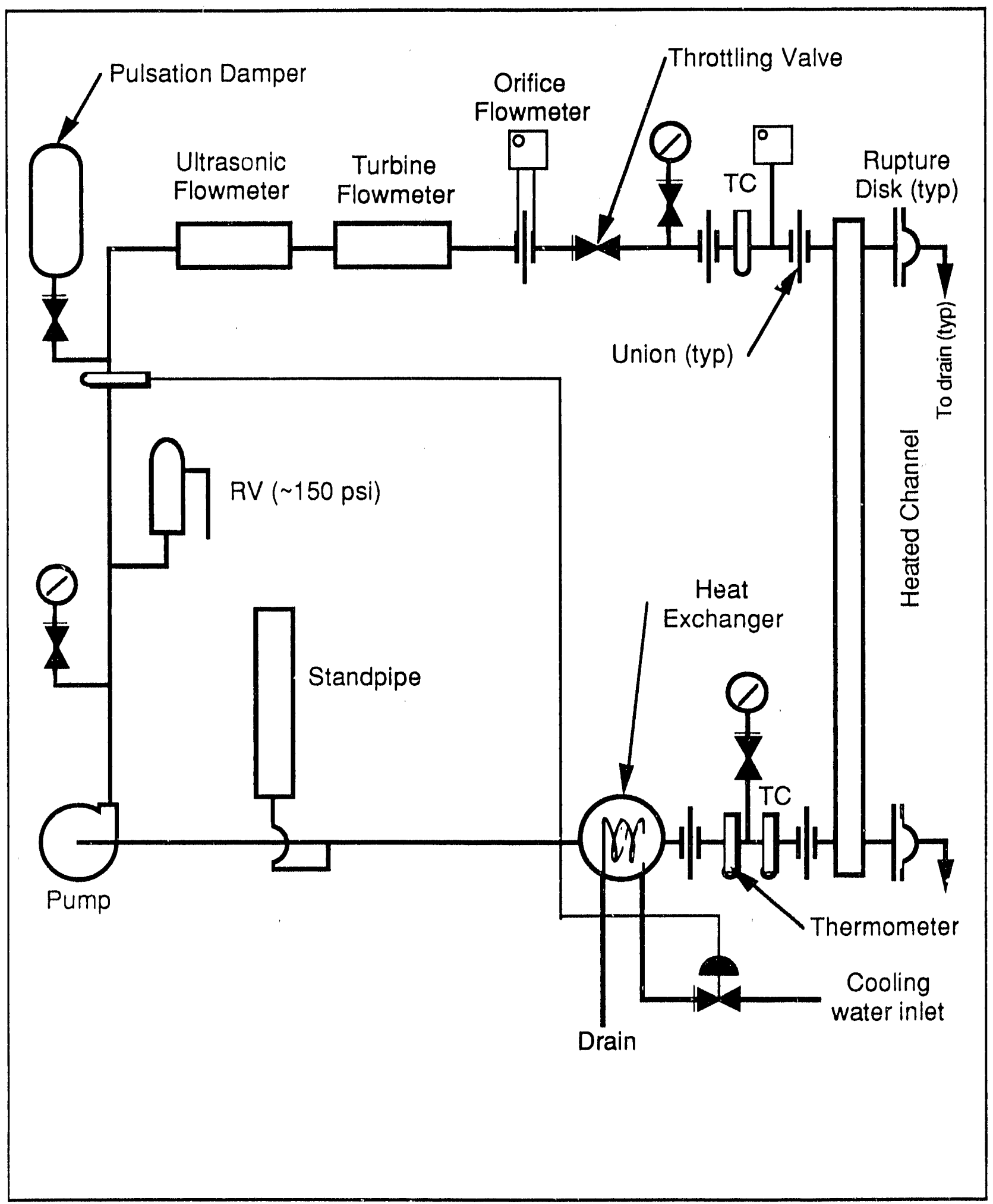

Figure 6, Test Loop Arrangement 


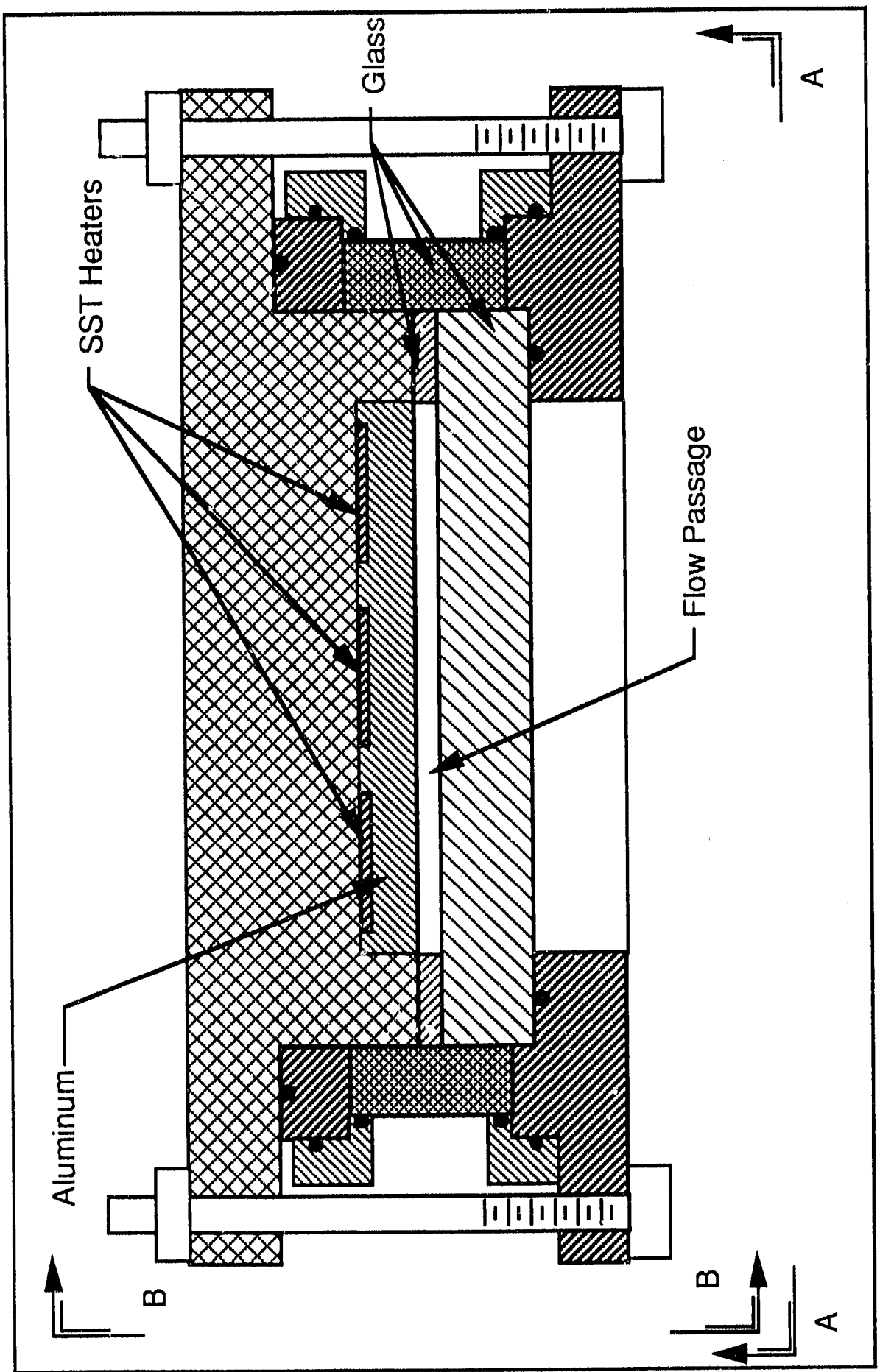

Figure 7, Test Channel Section 


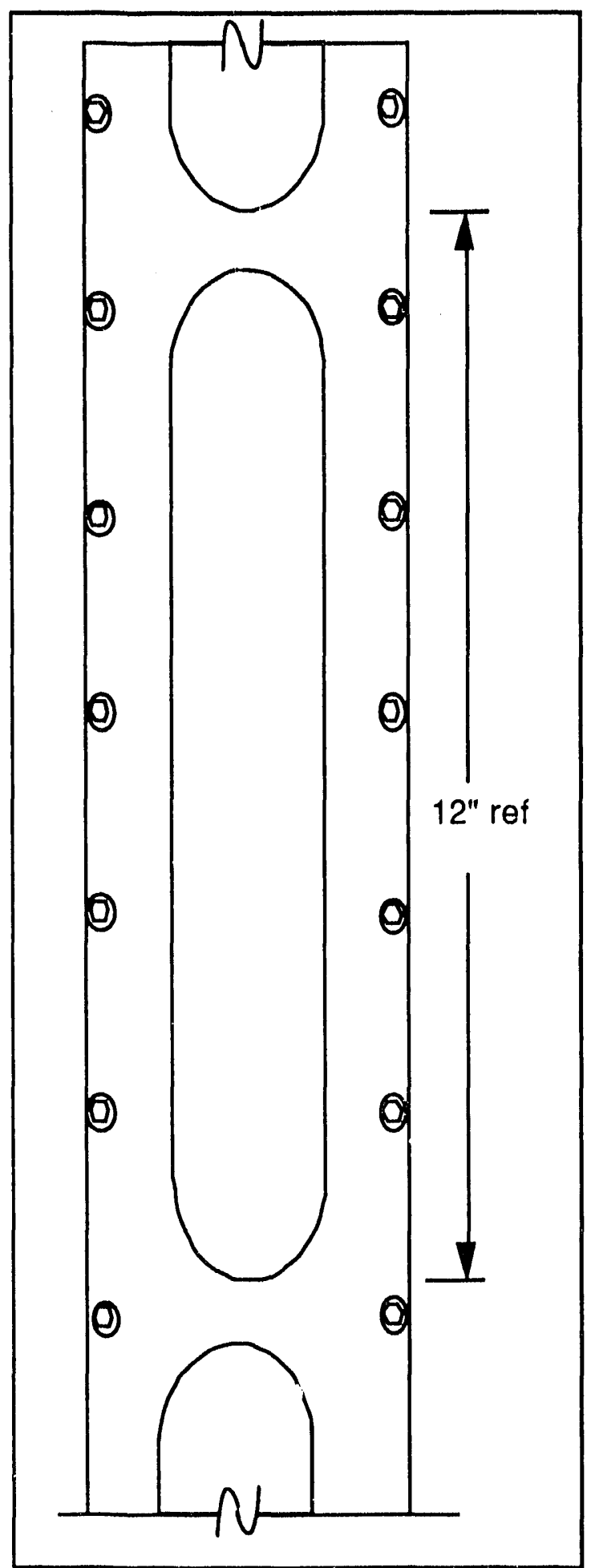

Figure 8, Test Channel Section AA 


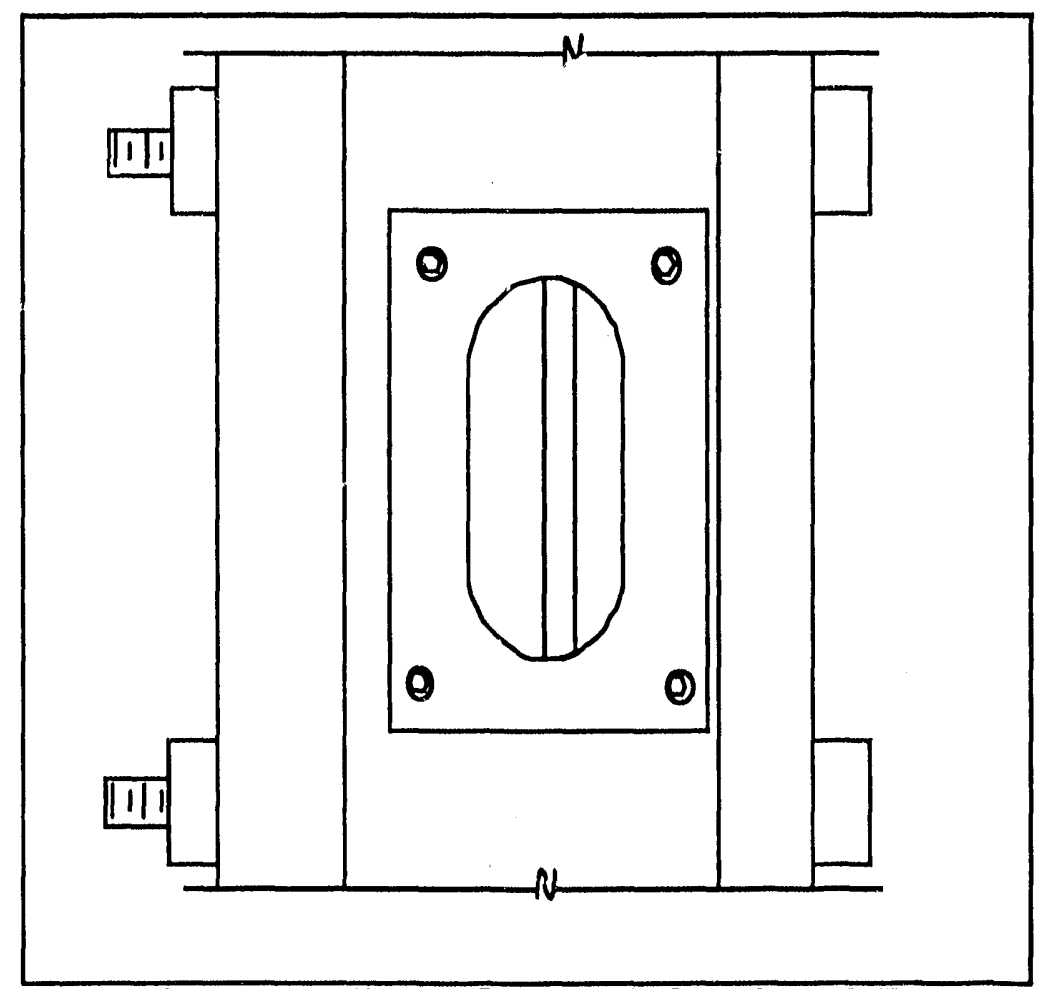

Figure 9, Test Channel Section BB 


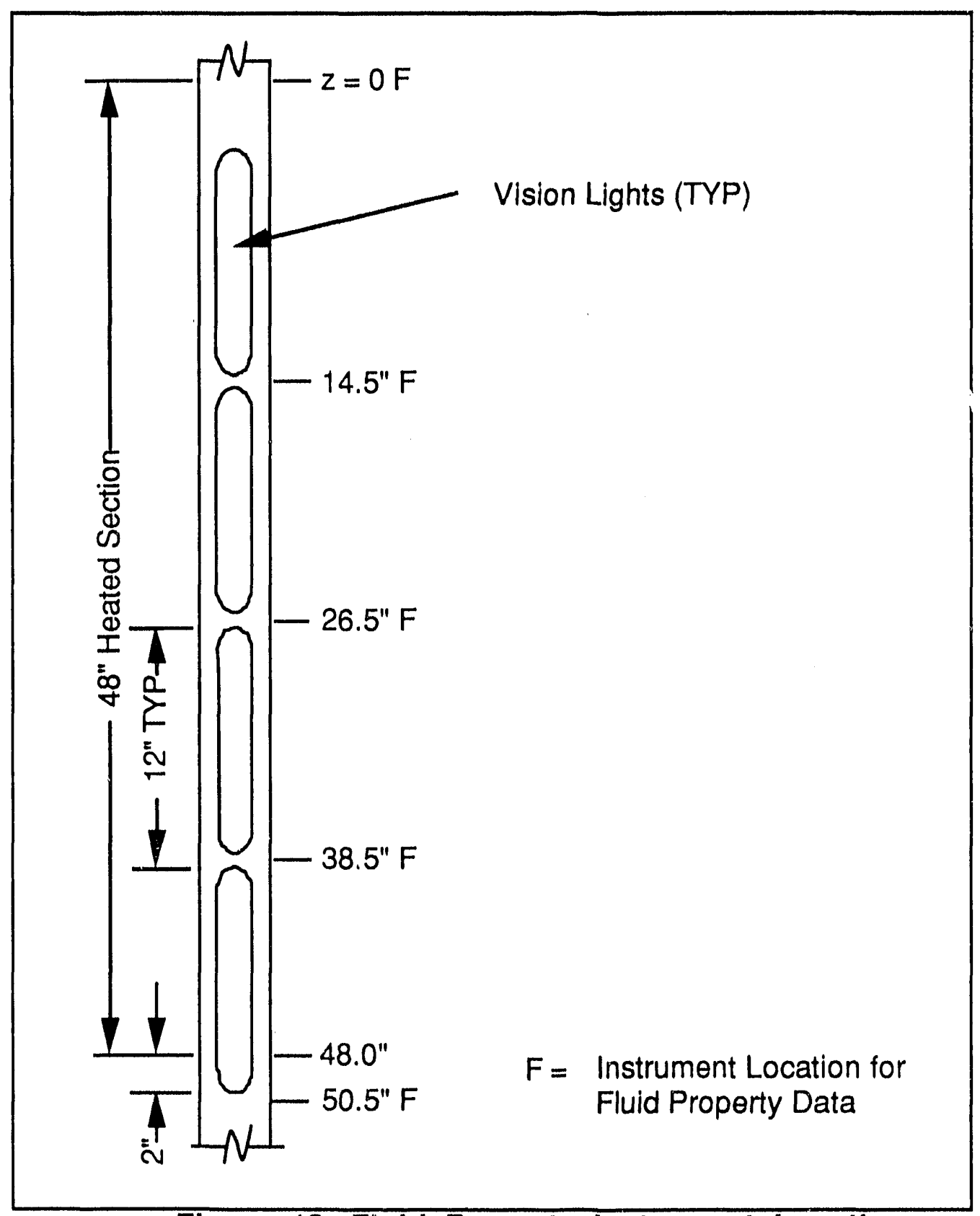

Figure 10, Fluid Property Instrument Locations 


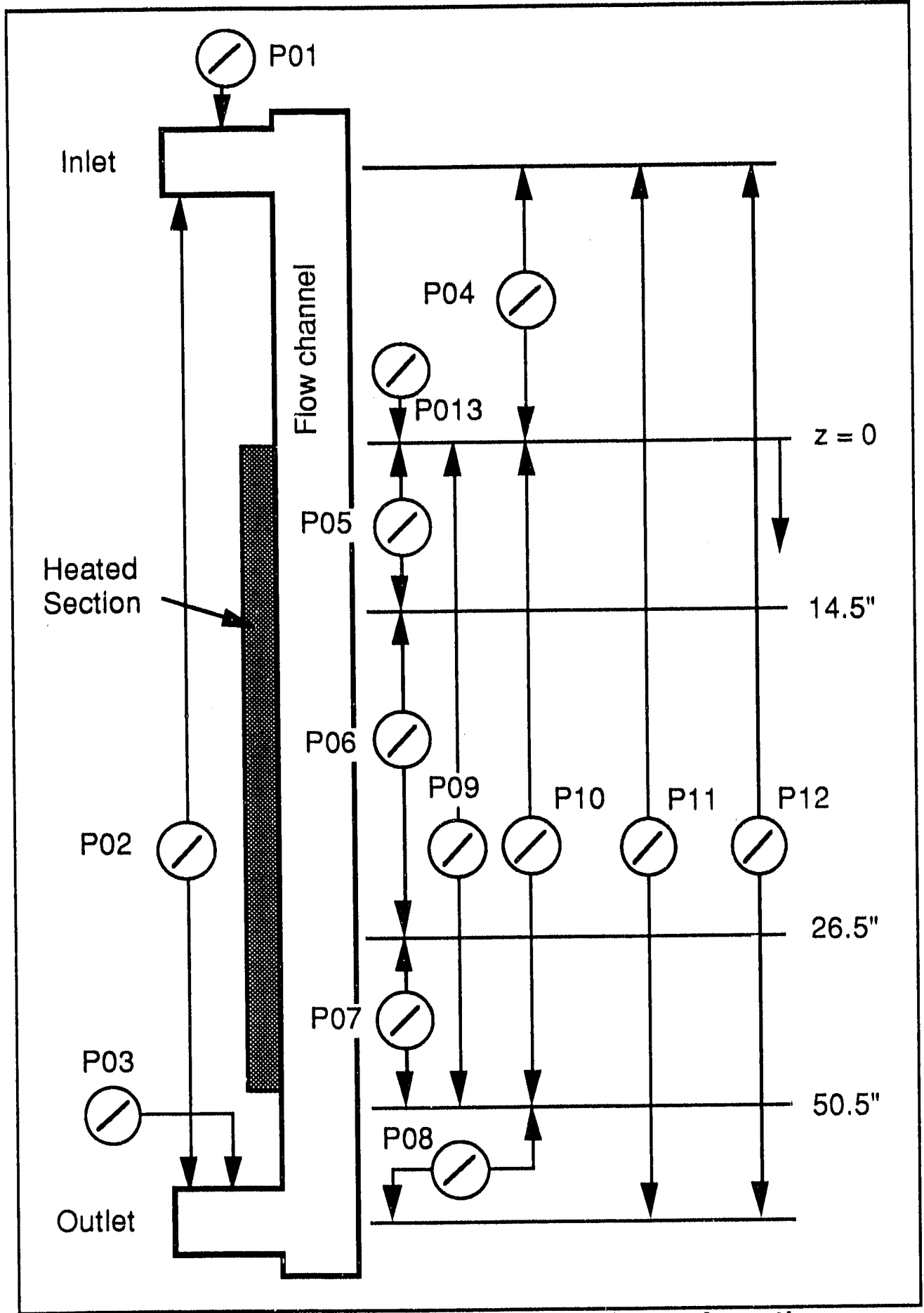

Figure 12, Pressure Transducer Locations 


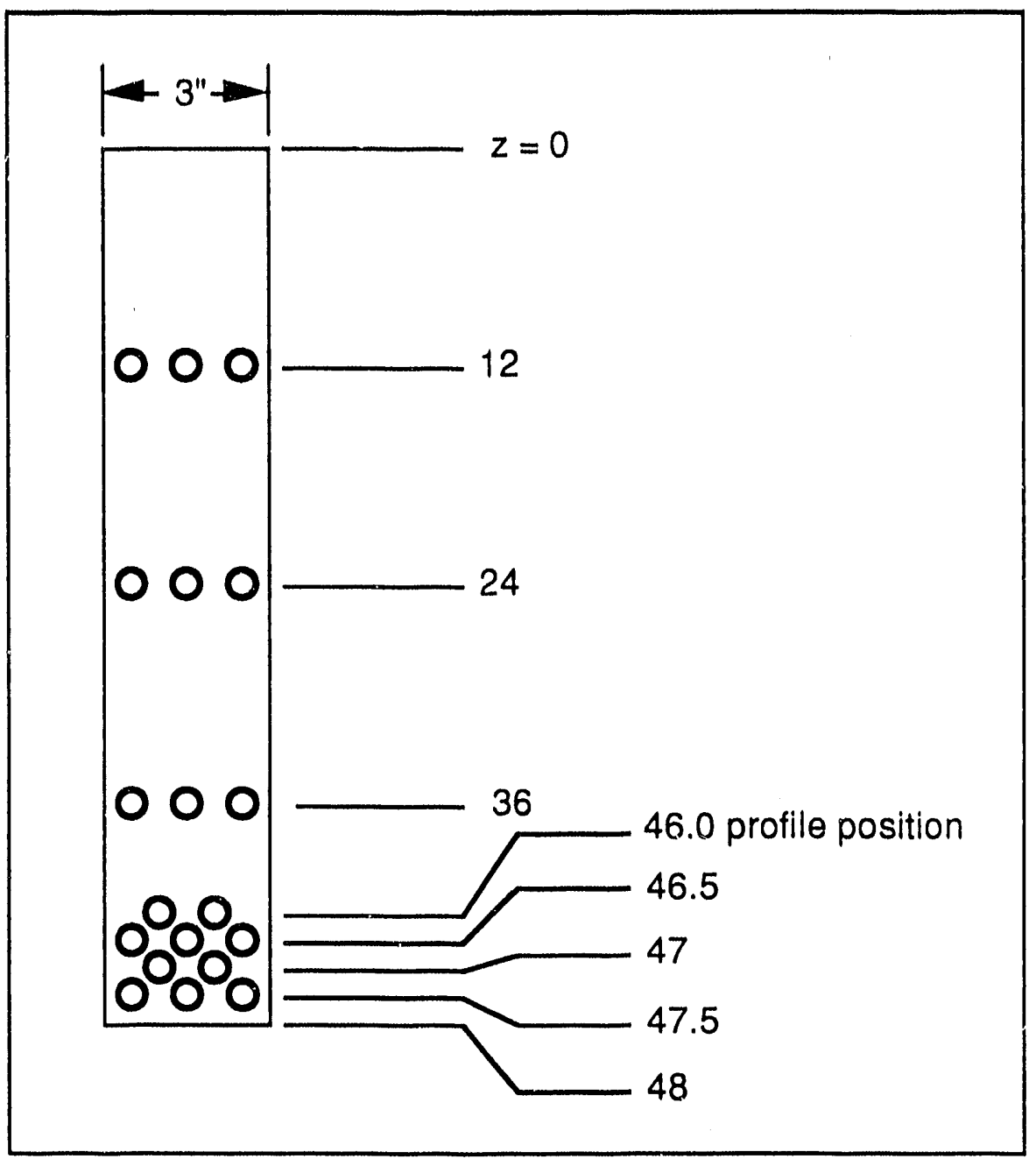

Figure 13, Heated Plate Thermocouple Positions 


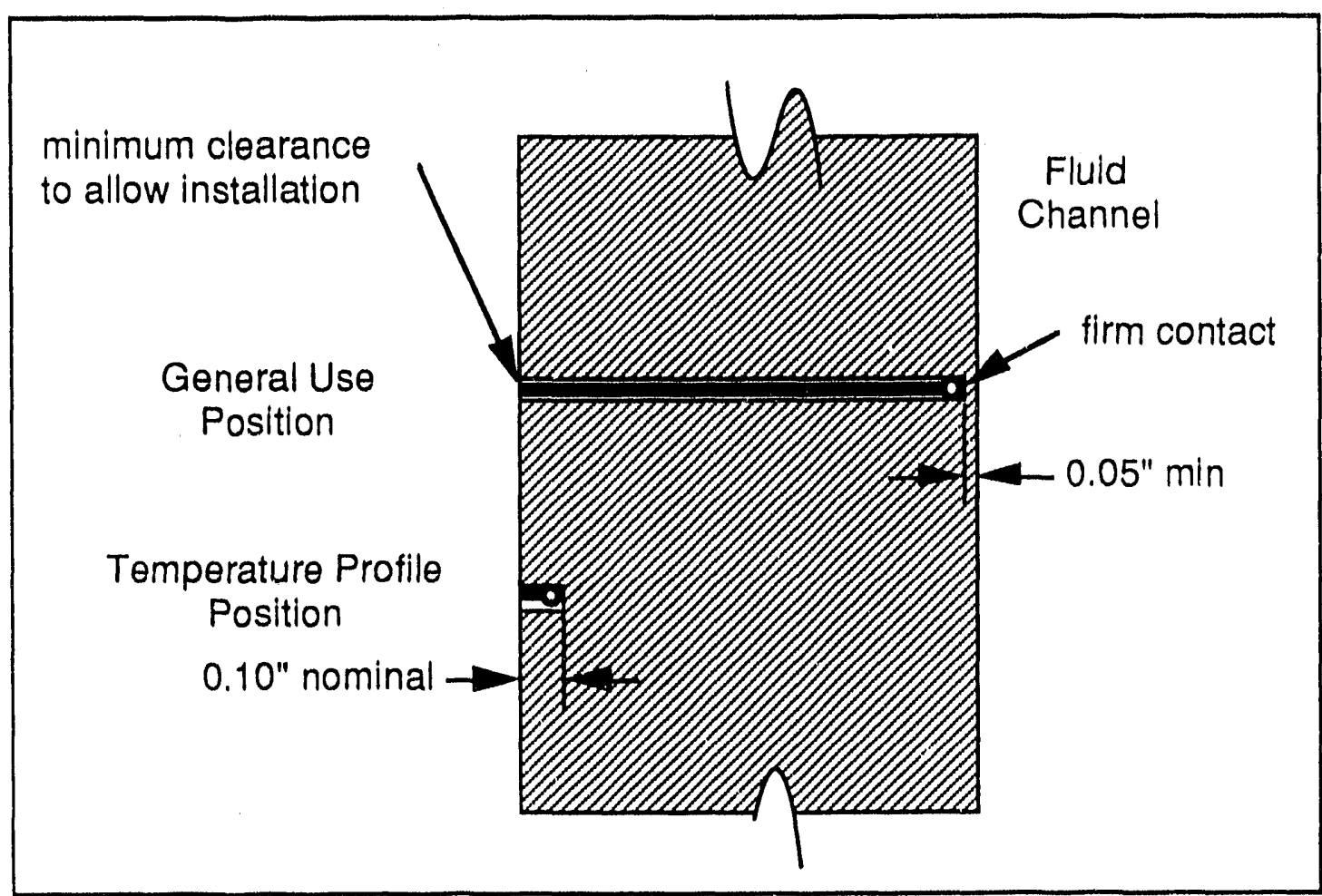

Figure 14, Heated Plate Thermocouple Installation Details 


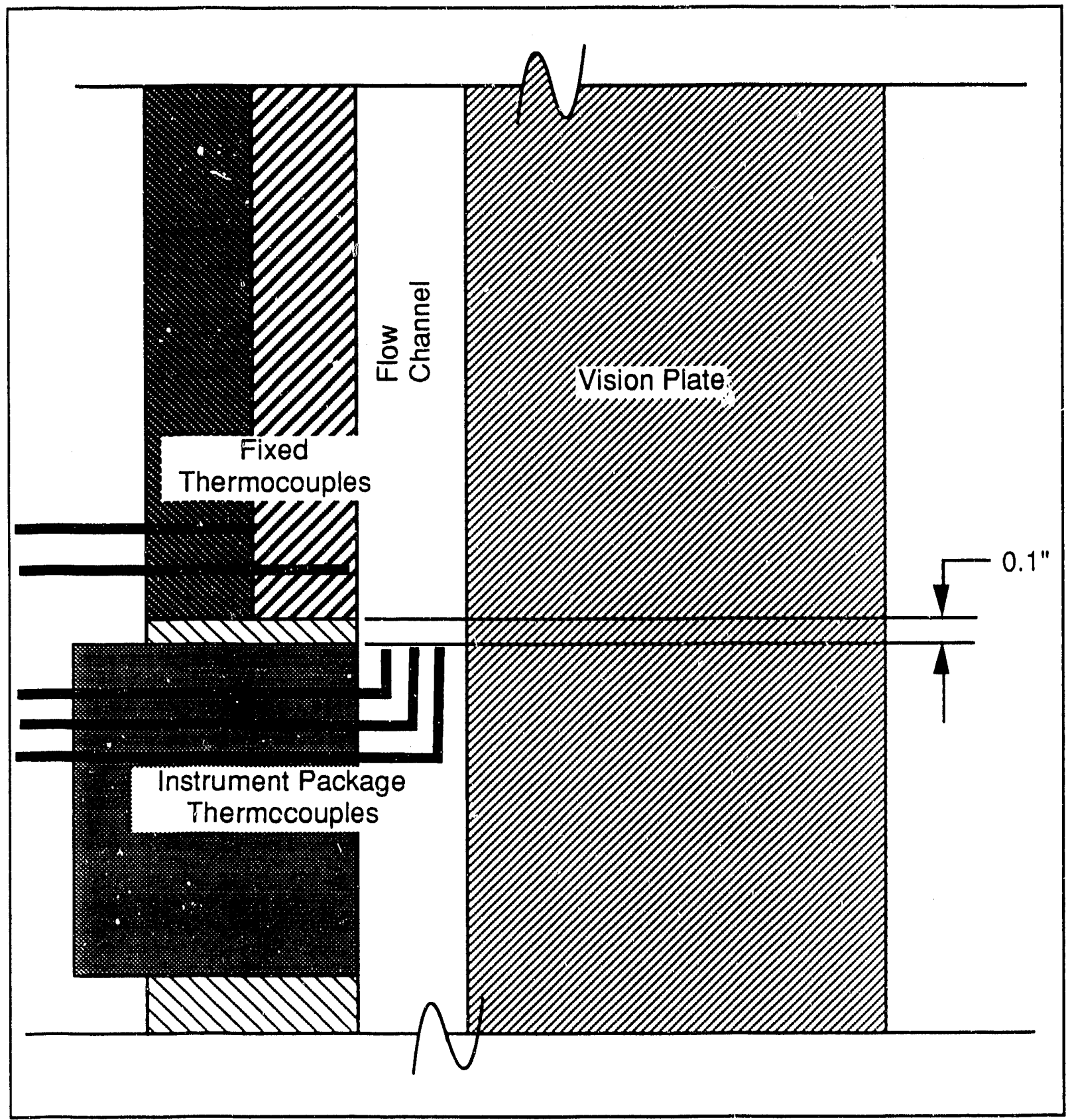

Figure 15, Instrument Package Installation 
Rev 0

Page 27 of 31

10/17/91

Behavior During Flow Instability

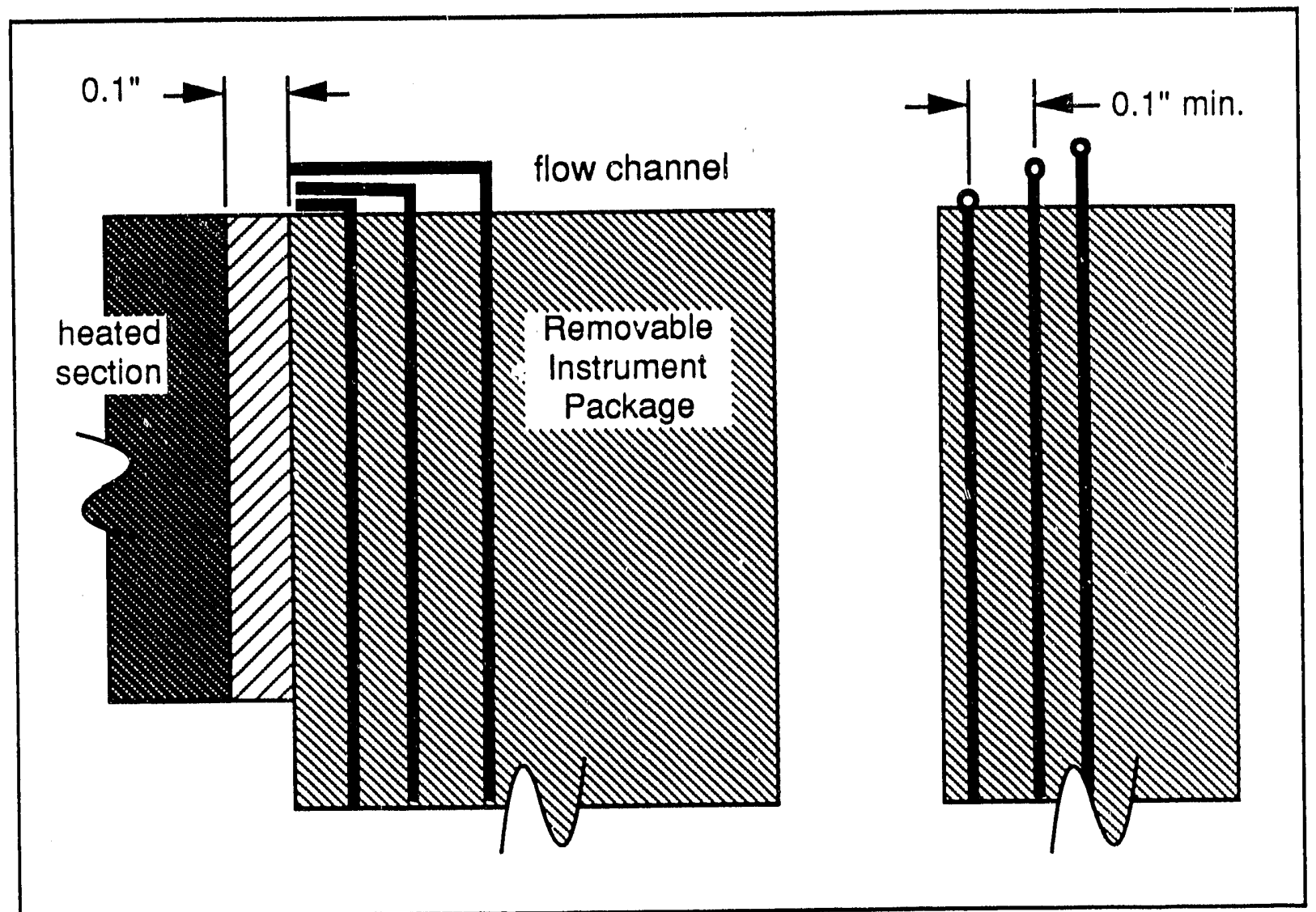

Figure 16, Instrument Package Details 


\section{Table 1}

Pressure Drop for a Mass Flow of 2,900,000 \#/hr-ft ${ }^{2}$

\begin{tabular}{|c|c|c|c|c|}
\hline $\begin{array}{c}\text { Temperature } \\
{ }^{\circ} \mathrm{F}\end{array}$ & $\begin{array}{c}\text { Density } \\
\# / \mathrm{ft}^{3}\end{array}$ & $\begin{array}{c}\text { Viscosity } \\
\# / h r-\mathrm{ft}\end{array}$ & Friction Factor & $\begin{array}{c}\text { Pressure Loss } \\
\mathrm{psi}\end{array}$ \\
\hline 140 & 60.4 & 0.89 & 0.005 & 11.7 \\
\hline 228 & 59.1 & 0.70 & 0.005 & 11.5 \\
\hline
\end{tabular}

\begin{tabular}{|l|c|}
\hline \multicolumn{2}{|c|}{ Table 2 } \\
\hline \multicolumn{2}{|c|}{ Exit Calculation Data } \\
\hline Inlet Temperature & $140^{\circ} \mathrm{F}$ \\
\hline Mass Flux & $914,000 \mathrm{\#} / \mathrm{hr}-\mathrm{ft}^{2}$ \\
\hline Quality at Exit & 0.10 \\
\hline Exit Pressure & $5 \mathrm{psig}$ \\
\hline Inlet Flow Area (Figure 2) & $0.0026 \mathrm{ft}^{2}$ \\
\hline Exit Flow Area (Figure 2) & $0.0233 \mathrm{ft}^{2}$ \\
\hline Inlet Velocity (test channel) & $2,510,000 \mathrm{ft} / \mathrm{hr}(697 \mathrm{fps})$ \\
\hline Exit Velocity (2" pipe) & $280,000 \mathrm{ft} / \mathrm{hr}(77.8 \mathrm{fps})$ \\
\hline
\end{tabular}




\section{Table 3}

Pressure Drop for a Heat Flux of 442,000 Btu/hr

\begin{tabular}{|c|c|c|c|c|}
\hline $\begin{array}{c}\text { Position } \\
\text { elevation, } z \text { ) } \\
\text { feet }\end{array}$ & $\begin{array}{c}\text { Temperature } \\
\mathrm{F}\end{array}$ & $\begin{array}{c}\text { Density } \\
\# / \mathrm{t}^{3}\end{array}$ & $\begin{array}{c}\text { Viscosity } \\
\# / h r-f t\end{array}$ & $\begin{array}{c}\text { Pressure } \\
\mathrm{psig}\end{array}$ \\
\hline inlet (4) & 140 & 60.4 & 0.89 & 66.3 \\
\hline $\begin{array}{c}\text { start of heated } \\
\text { section (0) }\end{array}$ & 140 & 60.4 & 0.89 & 67.4 \\
\hline $\begin{array}{c}\text { end of heated } \\
\text { section (-4) }\end{array}$ & 228 & 0.364 & 0.0366 & 14.8 \\
\hline $\begin{array}{c}\text { channel exit } \\
(-5)\end{array}$ & 228 & 0.364 & 0.0366 & 1.2 \\
\hline discharge (-5) & 228 & 0.364 & 0.0366 & 5.0 \\
\hline
\end{tabular}

\section{Table 4}

\section{Rupture Disk Design Information}

\begin{tabular}{|c|c|c|c|c|c|c|}
\hline $\begin{array}{c}\text { Specified } \\
\text { Burst } \\
\text { Pressure, } \\
\text { psi }\end{array}$ & $\begin{array}{c}\text { Manufacture's Range, } \\
\text { psi }\end{array}$ & \multicolumn{2}{c|}{$\begin{array}{c}\text { Rupture Disk } \\
\text { Tolerance, psi }\end{array}$} & \multicolumn{2}{c|}{ Purchased Rang, psi } \\
\hline & high & low & high & low & high & low \\
\hline 46.0 & 5.52 & 2.76 & 2.58 & 2.16 & 54.1 & 41.08 \\
\hline 42.8 & 6.85 & 3.42 & 2.48 & 1.97 & 52.1 & 37.41 \\
\hline
\end{tabular}




\section{Table 5}

\section{Instrument List}

\begin{tabular}{|c|c|c|c|c|c|c|}
\hline ID Number & Description & Range & Tolerance & $\begin{array}{c}\text { Uncer- } \\
\text { tainty Goal }\end{array}$ & $\begin{array}{l}\text { M\&TE } \\
\text { Number }\end{array}$ & $\begin{array}{l}\text { M\&TE } \\
\text { Category }\end{array}$ \\
\hline P01 & Pressure gage, channel inlet & 0 to $60 \mathrm{psig}$ & $\pm 3 p s i$ & & & 1 \\
\hline$\overline{\mathrm{PO2}}$ & Pressure gage & $01060 \mathrm{psid}$ & $\pm 3 \mathrm{psi}$ & & & 1 \\
\hline P03 & Pressure gage, channel outlet & $\begin{array}{c}-10 \text { to } 30 \\
\text { psig }\end{array}$ & $\pm 3 p s i$ & & & 1 \\
\hline$\overline{\mathrm{P}} \overline{04}$ & Pressure gage & 0 to 10 psid & $\pm 0.5 \mathrm{psl}$ & & & 1 \\
\hline$\overline{P 05}$ & Pressure gage & 0 to 5 psid & $\pm 0.03 \mathrm{ps}$ & & & 1 \\
\hline P06 & Pressure gage & 0 to $20 \mathrm{psid}$ & $\pm 1 \mathrm{ps}$ & & & 1 \\
\hline P07 & Pressure gage & 0 to $20 \mathrm{psid}$ & $\pm 1 \mathrm{ps} \mid$ & & & 1 \\
\hline $\mathrm{P08}$ & Pressure gage & 0 to 30 psid & $\pm 3 \mathrm{psi}$ & & & 1 \\
\hline P09 & Pressure gage & 0 to 5 psid & $\pm 0.03 \mathrm{psi}$ & & & 1 \\
\hline $\mathrm{P} 10$ & Pressure gage & 0 to 10 psid & $\pm 0.5 \mathrm{psi}$ & & & $T$ \\
\hline$\overline{P 11}$ & Pressure gage & 0 to 10 psid & $\pm 0.5 \mathrm{psi}$ & & & 1 \\
\hline$\overline{\mathrm{P} 12}$ & Pressure gage & 0 to 60 psid & $\pm 3 \mathrm{ps}$ & & & 1 \\
\hline$\overline{P 13}$ & Pressure gage & 0 to $60 \mathrm{psig}$ & $\pm 3 \mathrm{psi}$ & & & 1 \\
\hline$\overline{P 14}$ & Pressure gage, pump discharge & $\begin{array}{l}0 \text { to } 200 \\
\text { psia }\end{array}$ & $\pm 5 \mathrm{ps}$ & & & 2 \\
\hline$\overline{P 15}$ & Pressure gage, pump suction & $\begin{array}{c}-10 \text { to } 0 \\
\text { psig }\end{array}$ & $\pm 2 \mathrm{psi}$ & & & 2 \\
\hline FM00.0.1 & Water Flowmeter (electric) & $01011 \mathrm{gpm}$ & $0.2 \mathrm{gpm}$ & & & 1 \\
\hline & Water Flowmeter (rotameter) & 0 to $11 \mathrm{gpm}$ & $0.2 \mathrm{gpm}$ & & & 1 \\
\hline FM00.0.2 & Water Flowmeter (electric) & 0 to $11 \mathrm{gpm}$ & $0.2 \mathrm{gpm}$ & & & 1 \\
\hline & Water Flowmeter (rotameter) & 0 to $11 \mathrm{gpm}$ & $0.2 \mathrm{gpm}$ & & & 1 \\
\hline & & & & & & \\
\hline TFO0.0-1 & Thermocouple, Typo $E_{1} 1 / 32^{n}$ & 0 to $300^{\circ} \mathrm{C}$ & $\pm 1.7^{\circ} \mathrm{C}$ & $\pm 1.0^{\circ} \mathrm{C}$ & & 1 \\
\hline TC12.0-1 & Thermocouple, Type E, 0.01" & 0 to $300^{\circ} \mathrm{C}$ & $\pm 1.7^{\circ} \mathrm{C}$ & $\pm 1.0^{\circ} \mathrm{C}$ & & 1 \\
\hline TC12.0-2 & Thermocouple, Type $E, 0.01^{\prime \prime}$ & 0 to $300^{\circ} \mathrm{C}$ & $\pm 1.7^{\circ} \mathrm{C}$ & $\pm 1.0^{\circ} \mathrm{C}$ & & 1 \\
\hline TC12.0-3 & Thermocouple, Type E, 0.01" & 0 to $300^{\circ} \mathrm{C}$ & $\pm 1.7^{\circ} \mathrm{C}$ & $\pm 1.0^{\circ} \mathrm{C}$ & & 1 \\
\hline TF14.5-1 & Thermocouple, Type $E$, bare & 0 to $300^{\circ} \mathrm{C}$ & $\pm 1.7^{\circ} \mathrm{C}$ & $\pm 1.0^{\circ} \mathrm{C}$ & & 1 \\
\hline TF14.5.2 & Thermocouple, Type E, bare & 0 to $300^{\circ} \mathrm{C}$ & $\pm 1.7^{\circ} \mathrm{C}$ & $\pm 1.0^{\circ} \mathrm{C}$ & & 1 \\
\hline TC24.0-1 & Thermocouple, Type E, 0.01" & 0 to $300^{\circ} \mathrm{C}$ & $\pm 1.7^{\circ} \mathrm{C}$ & $\pm 1.0^{\circ} \mathrm{C}$ & & 1 \\
\hline TC24.0-2 & Thermocouple, Type E, $0.01^{n}$ & $010300^{\circ} \mathrm{C}$ & $\pm 1.7^{\circ} \mathrm{C}$ & $\pm 1.0^{\circ} \mathrm{C}$ & & 1 \\
\hline TC24.0-3 & Thermocouple, Type E, $0.01^{n}$ & 0 to $300^{\circ} \mathrm{C}$ & $\pm 1.7^{\circ} \mathrm{C}$ & $\pm 1.0^{\circ} \mathrm{C}$ & & 1 \\
\hline TF26.5-1 & Thermocouple, Type E, bare & 0 to $300^{\circ} \mathrm{C}$ & $\pm 1.7^{\circ} \mathrm{C}$ & $\pm 1.0^{\circ} \mathrm{C}$ & & 1 \\
\hline TF26.5-2 & Thermocouple, Type E, bare & 0 to $300^{\circ} \mathrm{C}$ & $\pm 1.7^{\circ} \mathrm{C}$ & $\pm 1.0^{\circ} \mathrm{C}$ & & 1 \\
\hline TC36.0-1 & Thermocouple, Type E, $0.01^{n}$ & 0 to $300^{\circ} \mathrm{C}$ & $\pm 1.7^{\circ} \mathrm{C}$ & $\pm 1.0^{\circ} \mathrm{C}$ & & 1 \\
\hline TC36.0-2 & Thermocouple, Type E, 0.01" & 0 to $300^{\circ} \mathrm{C}$ & $\pm 1.7^{\circ} \mathrm{C}$ & $\pm 1.0^{\circ} \mathrm{C}$ & & 1 \\
\hline TC36.0-3 & Thermocouple, Type E, $0.01^{\prime \prime}$ & 0 to $300^{\circ} \mathrm{C}$ & $\pm 1.7^{\circ} \mathrm{C}$ & $\pm 1.0^{\circ} \mathrm{C}$ & & 1 \\
\hline TF38.5-1 & Thermocouple, Type E, bare & 0 to $300^{\circ} \mathrm{C}$ & $\pm 1.7^{\circ} \mathrm{C}$ & $\pm 1.0^{\circ} \mathrm{C}$ & & 1 \\
\hline TF38.5.1 & Thermocouple, Type E, bare & $010300^{\circ} \mathrm{C}$ & $\pm 1.7^{\circ} \mathrm{C}$ & $\pm 1.0^{\circ} \mathrm{C}$ & & 1 \\
\hline TC46.0-1 & Thermocouple, Type $E, 0.01^{\prime \prime}$ & $010300^{\circ} \mathrm{C}$ & $\pm 1.7^{\complement} \mathrm{C}$ & $\pm 1.0^{\circ} \mathrm{C}$ & & 1 \\
\hline TC46.0.2 & Thermocouple, Type $E, 0.01^{\prime \prime}$ & 0 to $300^{\circ} \mathrm{C}$ & $\pm 1.7^{\circ} \mathrm{C}$ & $\pm 1.0^{\circ} \mathrm{C}$ & & 1 \\
\hline$T C 46.5-1$ & Thermocouple, Type E, $0.01^{\prime \prime}$ & $010300^{\circ} \mathrm{C}$ & $\pm 1.7^{\circ} \mathrm{C}$ & $\pm 1.0^{\circ} \mathrm{C}$ & & 1 \\
\hline TC46.5-2 & Thermocouple, Type E, 0.01" & $010300^{\circ} \mathrm{C}$ & $\pm 1.7^{\circ} \mathrm{C}$ & $\pm 1.0^{\circ} \mathrm{C}$ & & 1 \\
\hline TC46.5-3 & Thermocouple. Type E, 0.01" & $010300^{\circ} \mathrm{C}$ & $\pm 1.7^{\circ} \mathrm{C}$ & $\pm 1.0^{\circ} \mathrm{C}$ & & 1 \\
\hline TC47.0-1 & Thermocouple, Type E, $0.01^{\prime \prime}$ & 0 to $300^{\circ} \mathrm{C}$ & $\pm 1.7^{\circ} \mathrm{C}$ & $\pm 1.0^{\circ} \mathrm{C}$ & & 1 \\
\hline TC47.0-2 & Thermocouple, Type $E, 0.01^{\prime \prime}$ & 0 to $300^{\circ} \mathrm{C}$ & $\pm 1.7^{\circ} \mathrm{C}$ & $\pm 1.0^{\circ} \mathrm{C}$ & & 1 \\
\hline
\end{tabular}


Rev 0

Page 31 of 31

Design Input Document, Boiling Behavior During Flow Instability

Table 5 (con't)

Instrument List

\begin{tabular}{|l|l|c|c|c|c|c|}
\hline TC47.5-1 & Thermocouple, Type $\mathrm{E}, 0.01^{\prime \prime}$ & 0 to $300^{\circ} \mathrm{C}$ & $\pm 1.7^{\circ} \mathrm{C}$ & $\pm 1.0^{\circ} \mathrm{C}$ & & 1 \\
\hline TC47.5-2 & Thermocouple, Type $\mathrm{E}, 0.01^{\prime \prime}$ & 0 to $300^{\circ} \mathrm{C}$ & $\pm 1.7^{\circ} \mathrm{C}$ & $\pm 1.0^{\circ} \mathrm{C}$ & & 1 \\
\hline TC47.5-2 & Thermocouple, Type $\mathrm{E}, 0.01^{\prime \prime}$ & 0 to $300^{\circ} \mathrm{C}$ & $\pm 1.7^{\circ} \mathrm{C}$ & $\pm 1.0^{\circ} \mathrm{C}$ & & 1 \\
\hline TF49.0-1 & $\begin{array}{l}\text { Thermocouple, Type E, bare } \\
\text { (package) }\end{array}$ & 0 to $300^{\circ} \mathrm{C}$ & $\pm 1.7^{\circ} \mathrm{C}$ & $\pm 1.0^{\circ} \mathrm{C}$ & & 1 \\
\hline TF49.0-2 & $\begin{array}{l}\text { Thermocouple, Type E, bare } \\
\text { (package) }\end{array}$ & 0 to $300^{\circ} \mathrm{C}$ & $\pm 1.7^{\circ} \mathrm{C}$ & $\pm 1.0^{\circ} \mathrm{C}$ & & 1 \\
\hline TF49.0-3 & $\begin{array}{l}\text { Thermocouple, Type E, bare } \\
\text { (package) }\end{array}$ & 0 to $300^{\circ} \mathrm{C}$ & $\pm 1.7^{\circ} \mathrm{C}$ & $\pm 1.0^{\circ} \mathrm{C}$ & & 1 \\
\hline TF50.5-1 & Thermocouple, Type E, bare & 0 to $300^{\circ} \mathrm{C}$ & $\pm 1.7^{\circ} \mathrm{C}$ & $\pm 1.0^{\circ} \mathrm{C}$ & & 1 \\
\hline TF50.5-2 & Thermocouple, Type E, bare & 0 to $300^{\circ} \mathrm{C}$ & $\pm 1.7^{\circ} \mathrm{C}$ & $\pm 1.0^{\circ} \mathrm{C}$ & & 1 \\
\hline TF50.5-3 & Thermocouple, Type E, bare & 0 to $300^{\circ} \mathrm{C}$ & $\pm 1.7^{\circ} \mathrm{C}$ & $\pm 1.0^{\circ} \mathrm{C}$ & & 1 \\
\hline TF60.0-1 & Thermocouple, Type E, bare & 0 to $300^{\circ} \mathrm{C}$ & $\pm 1.7^{\circ} \mathrm{C}$ & $\pm 1.0^{\circ} \mathrm{C}$ & & 1 \\
\hline TF60.0-2 & Thermocouple, Type E, bare & 0 to $300^{\circ} \mathrm{C}$ & $\pm 1.7^{\circ} \mathrm{C}$ & $\pm 1.0^{\circ} \mathrm{C}$ & & 1 \\
\hline & Thermometer & 0 to $120^{\circ} \mathrm{C}$ & $\pm 0.5^{\circ} \mathrm{C}$ & $\pm 0.5^{\circ} \mathrm{C}$ & & 1 \\
\hline & & 0 to $5 \mathrm{mV}$ & $\pm 0.1 \%$ & & & 1 \\
\hline & Voltmeter/1 & nominal & $\pm 0.1 \% \%$ & & & 1 \\
\hline & Shunt/1 & & & & & NA \\
\hline
\end{tabular}



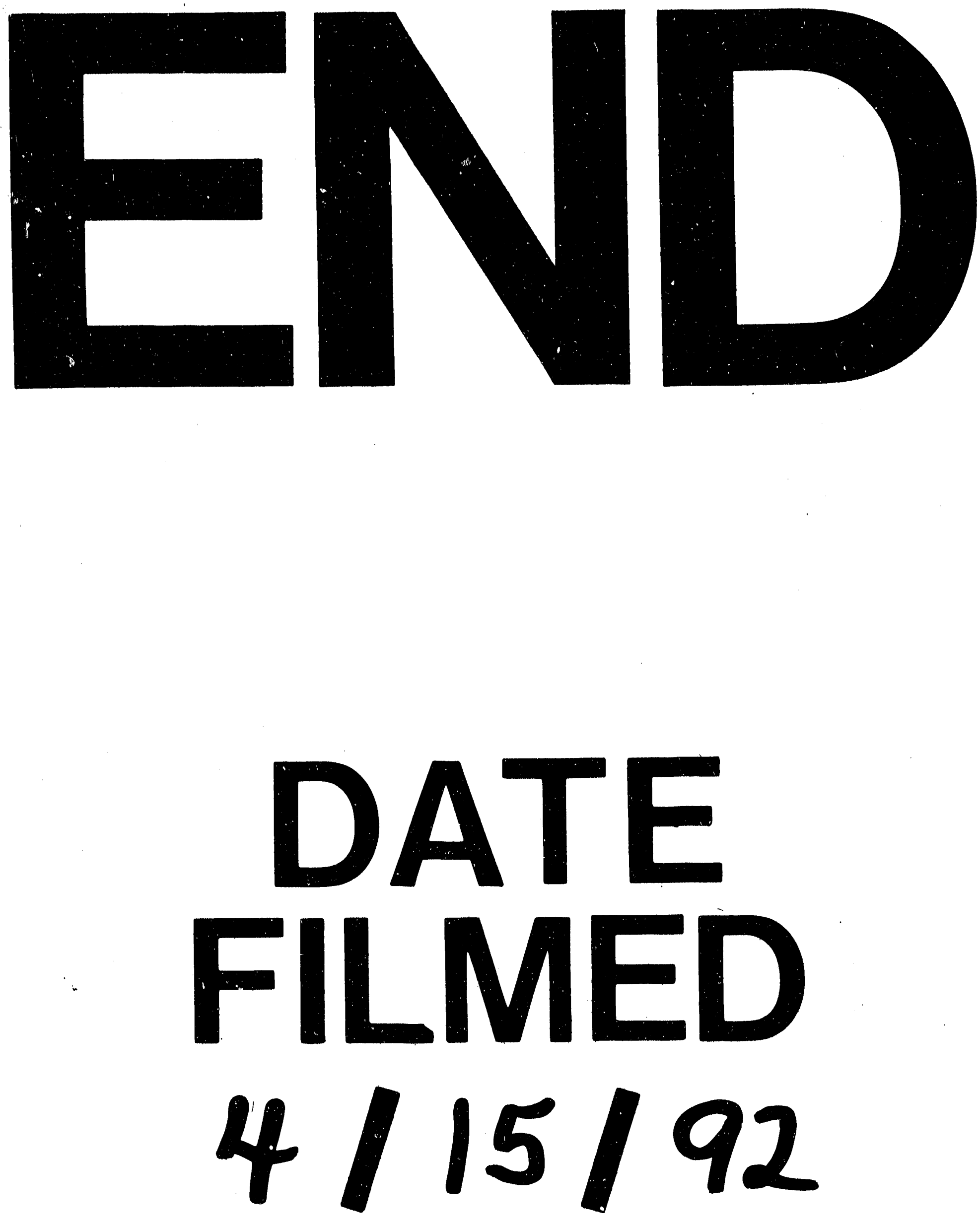
